\title{
Coccolithophores on the north-west European shelf: calcification rates and environmental controls
}

\author{
A. J. Poulton ${ }^{1}$, M. C. Stinchcombe ${ }^{1}$, E. P. Achterberg ${ }^{2,3}$, D. C. E. Bakker ${ }^{4}$, C. Dumousseaud ${ }^{2}$, H. E. Lawson ${ }^{1,2}$, \\ G. A. Lee ${ }^{4}$, S. Richier ${ }^{2}$, D. J. Suggett ${ }^{5,6}$, and J. R. Young ${ }^{7}$ \\ ${ }^{1}$ National Oceanography Centre, University of Southampton Waterfront Campus, European Way, Southampton, UK \\ ${ }^{2}$ Ocean and Earth Science, National Oceanography Centre Southampton, University of Southampton, Southampton, UK \\ ${ }^{3}$ GEOMAR Helmholtz Centre for Ocean Research, 24148 Kiel, Germany \\ ${ }^{4}$ Centre for Ocean and Atmospheric Sciences, School of Environmental Sciences, University of East Anglia, Norwich \\ Research Park, Norwich, UK \\ ${ }^{5}$ University of Essex, Colchester, Essex, UK \\ ${ }^{6}$ Plant Functional Biology and Climate Change Cluster, University of Sydney, Sydney, Australia \\ ${ }^{7}$ University College London, London, UK
}

Correspondence to: A. J. Poulton (alex.poulton@noc.ac.uk)

Received: 21 January 2014 - Published in Biogeosciences Discuss.: 18 February 2014

Revised: 19 June 2014 - Accepted: 19 June 2014 - Published: 25 July 2014

\begin{abstract}
Coccolithophores are a key functional group in terms of the pelagic production of calcium carbonate (calcite), although their contribution to shelf sea biogeochemistry, and how this relates to environmental conditions, is poorly constrained. Measurements of calcite production (CP) and coccolithophore abundance were made on the northwest European shelf to examine trends in coccolithophore calcification along natural gradients of carbonate chemistry, macronutrient availability and plankton composition. Similar measurements were also made in three bioassay experiments where nutrient (nitrate, phosphate) and $p \mathrm{CO}_{2}$ levels were manipulated. Nanoflagellates $(<10 \mu \mathrm{m})$ dominated chlorophyll biomass and primary production (PP) at all but one sampling site, with $\mathrm{CP}$ ranging from 0.6 to $9.6 \mathrm{mmol} \mathrm{C} \mathrm{m}^{-2} \mathrm{~d}^{-1}$. High $\mathrm{CP}$ and coccolithophore abundance occurred in a diatom bloom in fully mixed waters off Heligoland, but not in two distinct coccolithophore blooms in the central North Sea and Western English Channel. Coccolithophore abundance and CP showed no correlation with nutrient concentrations or ratios, while significant $(p<0.01)$ correlations between $\mathrm{CP}$, cell-specific calcification (cell-CF) and irradiance in the water column highlighted how light availability exerts a strong control on pelagic CP. In the experimental bioassays, Emiliania-huxleyi-dominated coccolithophore communities in shelf waters (northern North Sea,
\end{abstract}

Norwegian Trench) showed a strong response in terms of $\mathrm{CP}$ to combined nitrate and phosphate addition, mediated by changes in cell-CF and growth rates. In contrast, an offshore diverse coccolithophore community (Bay of Biscay) showed no response to nutrient addition, while light availability or mortality may have been more important in controlling this community. Sharp decreases in $\mathrm{pH}$ and a rough halving of calcite saturation states in the bioassay experiments led to decreased CP in the Bay of Biscay and northern North Sea, but not the Norwegian Trench. These decreases in CP were related to slowed growth rates in the bioassays at elevated $p \mathrm{CO}_{2}(750 \mu \mathrm{atm})$ relative to those in the ambient treatments. The combined results from our study highlight the variable coccolithophore responses to irradiance, nutrients and carbonate chemistry in north-west European shelf waters, which are mediated by changes in growth rates, cell-CF and species composition.

\section{Introduction}

High cellular levels of calcite production in coccolithophores, maintained through the rapid production of individual cellular plates of calcite (coccoliths), facilitate this group with a strong influence on the marine carbon cycle 
through the production and export of calcite, as well as modification of air-sea carbon dioxide $\left(\mathrm{CO}_{2}\right)$ fluxes (Holligan et al., 1993a). As a group, coccolithophores are globally distributed, from the subpolar Arctic to the Antarctic and from the open ocean to shelf seas. Many coccolithophore species (e.g. Emiliania huxleyi, Gephyrocapsa muellerae) have cell diameters of 5-10 $\mu \mathrm{m}$, making them a potentially important component of the nanoflagellate (herein $<10 \mu \mathrm{m}$ ) community.

One of the most common coccolithophore species, E. huxleyi, often forms large-scale $\left(50-250 \times 10^{3} \mathrm{~km}^{2}\right)$ blooms in the open ocean (e.g. Iceland Basin), along continental shelves (e.g. Patagonian Shelf) and in shelf seas (e.g. North Sea, English Channel) (Iglesias-Rodriguez et al., 2002; Tyrrell and Merico, 2004). Such blooms are characterised by the excessive production and shedding of coccoliths into the surrounding waters (Balch et al., 1996a), giving a milky appearance and a high-reflectance signature in satellite images (Holligan et al., 1983). Formation of E. huxleyi blooms is often linked to warm, stratified conditions where silicic acid concentrations are low (limiting diatoms) and irradiance levels are high (e.g. Holligan et al., 1983). Other factors, notably iron availability (Poulton et al., 2013), may also be important in further regulating bloom formation in cold, nutrient-rich waters.

The north-west (NW) European Shelf was the first region where major coccolithophore blooms were recognised (Holligan et al., 1983, 1993b), and subsequent blooms in this area have been intensively studied (e.g. Van der Wal et al., 1995; Head et al., 1998; Rees et al., 2002; Harlay et al., 2010, 2011). However, few studies have made observations during non-bloom conditions, in the context of the biomass and production of the phytoplankton community as a whole, and with reference to potentially growth-regulating environmental factors. Several factors are thought to be key in promoting oceanic bloom formation by coccolithophores, including shallow mixed layers, high irradiances and temperatures, low nitrate to phosphate ratios and reduced microzooplankton grazing (Iglesias-Rodriguez et al., 2002; Tyrrell and Merico, 2004).

Oceanic blooms may be $>250000 \mathrm{~km}^{2}$ in areal extent (Raitsos et al., 2006), with average rates of calcite production of $\sim 1 \mathrm{~g} \mathrm{CaCO}_{3} \mathrm{~m}^{-2} \mathrm{~d}^{-1}\left(10 \mathrm{mmol} \mathrm{C} \mathrm{m}^{-2} \mathrm{~d}^{-1}\right)$ and standing stocks of $\sim 21 \mathrm{~g} \mathrm{CaCO}_{3} \mathrm{~m}^{-2}\left(210 \mathrm{mmol} \mathrm{C} \mathrm{m}^{-2} \mathrm{~d}^{-1}\right)$ which scale to $\sim 8.3 \times 10^{12} \mathrm{~g} \mathrm{CaCO}_{3}$ for entire blooms (Holligan et al., 1993a). Blooms associated with continental shelves often tend to be smaller in areal extent $\left(<100000 \mathrm{~km}^{2}\right)$ than oceanic features, with similar levels of calcite production (Harlay et al., 2010, 2011; Poulton et al., 2013) although species composition is a potentially important constraint on calcite standing stocks (Poulton et al., 2013). In contrast to oceanic regions where benthic calcite production is relatively low, benthic organisms in shallow shelf seas may exhibit significant calcite production and dominate shelf sea calcite production (Lebrato et al., 2010).
Shelf seas are also regions of extensive primary production, with 15 to $30 \%$ of global primary production occurring in waters shallower than $200 \mathrm{~m}$ despite these areas constituting less than $10 \%$ of the global ocean (Simpson and Sharples, 2012). Such high productivity is sustained by a seasonal shift in phytoplankton community composition from winter phytoplankton communities dominated by small $(<10 \mu \mathrm{m})$ flagellates to spring communities of highly productive diatoms $(>10 \mu \mathrm{m})$, and summer communities dominated again by small flagellates; however dinoflagellates and coccolithophores are also present during this time and may form sporadic but highly significant blooms (Widdicombe et al., 2010) in terms of shelf sea biogeochemistry.

The fraction of primary production associated with coccolithophore communities within this seasonal cycle is poorly constrained, with estimates only available for the open ocean and generally $<10 \%$ (or up to $40 \%$ during coccolithophore blooms; see Poulton et al., 2007, 2013). Such seasonality in phytoplankton community composition is driven by cycles in water-column stratification in spring through to summer and its breakdown in winter and through surface nutrient (nitrate, phosphate, silicate) drawdown during the stratified period; although strong tidal mixing can result in highly mixed areas throughout the year (Simpson and Sharples, 2012). During seasonal stratification, vertical segregation of the phytoplankton community also occurs, with picoplankton $(<2 \mu \mathrm{m})$ dominating upper nutrient-impoverished waters and larger-celled microplankton (herein $>10 \mu \mathrm{m}$; e.g. diatoms) occurring deeper in the nutrient-enriched thermocline (Hickman et al., 2012).

The effects of global environmental change (e.g. increased temperatures and ocean stratification, deoxygenation) on marine organisms and ecosystems is a pressing concern in biological oceanography. Marine calcifiers, with their calcite (e.g. coccolithophores) and aragonite (e.g. pteropods) shells, are of particular concern since they may be impacted by both global warming and ocean acidification, i.e. decreases in $\mathrm{pH}$ and mineral saturation states (e.g. calcite saturation state, $\Omega_{\mathrm{C}}$ ) as the oceans and seas take up anthropogenically released $\mathrm{CO}_{2}$ (Royal Society, 2005). The broad aim of the present study was therefore to quantify coccolithophore production and how it varied in relation to key environmental drivers, such as nutrient and light availability and carbonate chemistry $\left(\mathrm{pH}, \Omega_{\mathrm{C}}\right)$, in waters around the NW European Shelf during summer (June) 2011 (Fig. 1).

Two approaches were used to examine coccolithophore dynamics: (1) in situ sampling at sites characterising different pelagic environments (e.g. stratified shelf, mixed shelf, oceanic) around the NW European Shelf; and (2) small-scale bioassay experiments where the natural plankton communities were exposed to nutrient addition (nitrate, phosphate and silicate) and/or elevated $p \mathrm{CO}_{2}$ (with a target of $750 \mu \mathrm{atm}$ ). In this paper we examine bulk coccolithophore community calcite production (CP), coccolithophore abundance and cellular levels of calcification (cell-normalised calcification or 


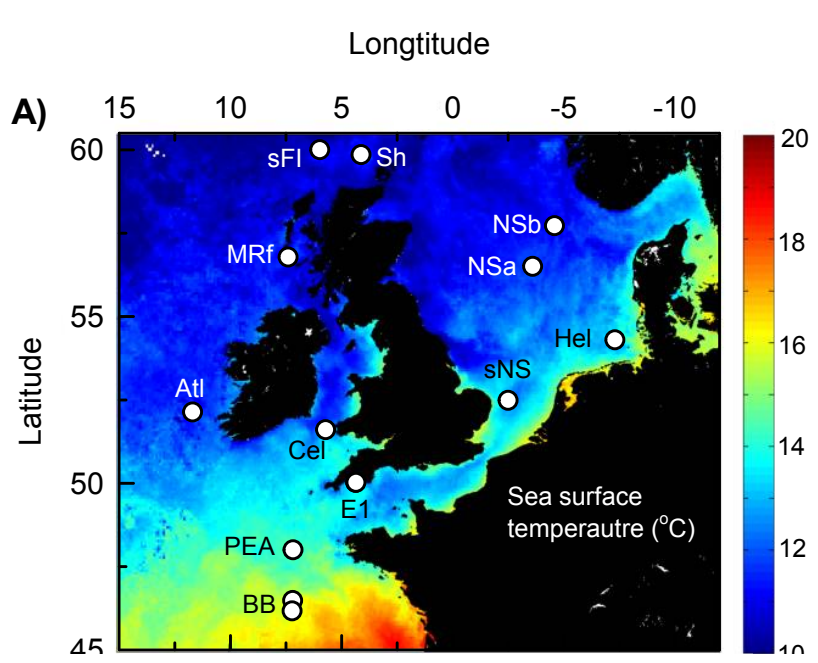

B)

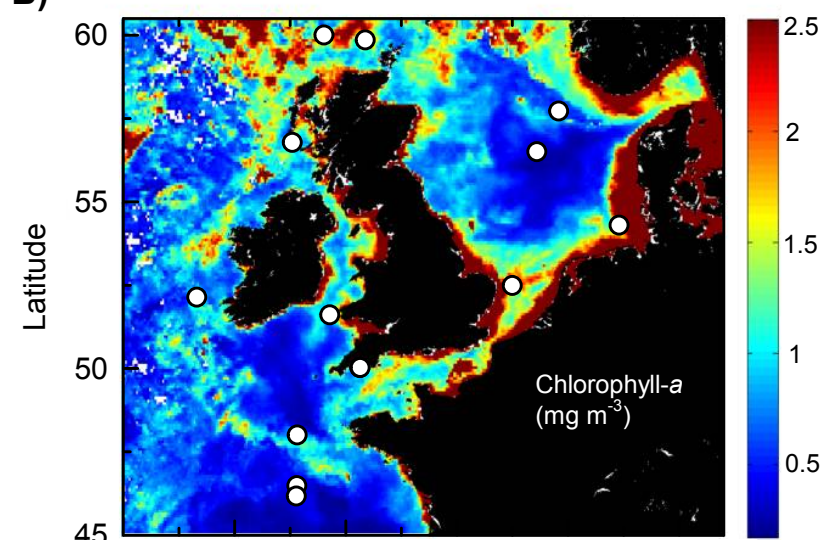

C)

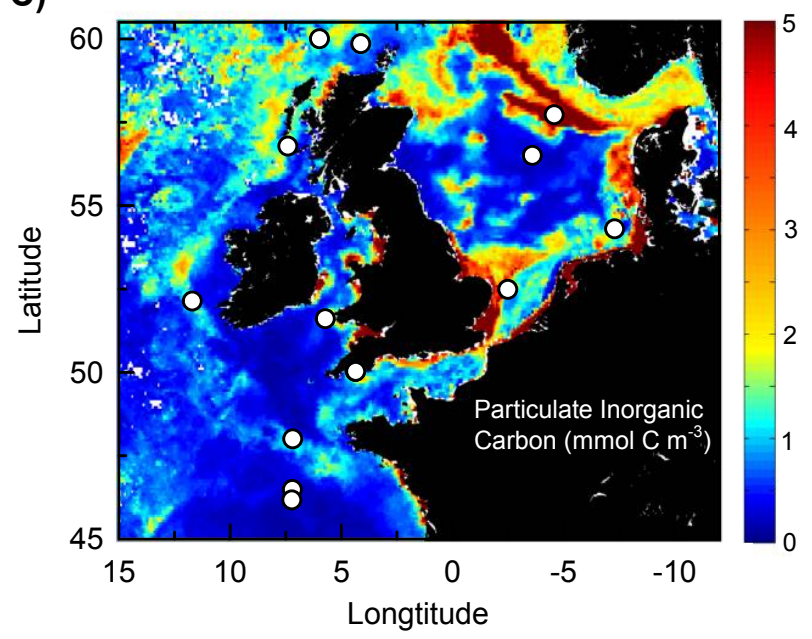

Figure 1. Maps showing the position of the daily productivity sampling stations (circles) and short-term (48 h) experiments (squares), superimposed on MODIS composites (June 2011) of (A) sea surface temperature $\left({ }^{\circ} \mathrm{C}\right),(\mathbf{B})$ surface chlorophyll $a,\left(\mathrm{mg} \mathrm{m}^{-3}\right)$ and $(\mathbf{C})$ surface particulate inorganic carbon $\left(\mathrm{mmol} \mathrm{C} \mathrm{m}^{-3}\right)$.

cell-CF) at the 14 sampling sites and in three bioassay experiments.

\section{Methods}

Sampling was carried out onboard the RRS Discovery (cruise number D366) which sailed from Liverpool (6 June 2011) to Liverpool (10 July 2011) around the NW European Shelf. Water sampling was carried out at 75 conductivity-temperature-depth (CTD) stations, of which 14 dawn (02:00 h to 04:30 h GMT) CTD stations (Fig. 1) were sampled at five light depths $(55,20,14,5$ and $1 \%$ of surface irradiance) for rate measurements (primary production, calcite production), biomass (chlorophyll $a$ ), phytoplankton community structure, macronutrients (nitrate + nitrite, phosphate, silicic acid) and carbonate chemistry.

The 14 sampling stations (Fig. 1; Table 1) were located at Mingulay Reef (MRf), the Atlantic coast (Atl) off Ireland, the central Celtic Sea (Cel), the Western English Channel Observatory (E1), the Bay of Biscay (BB), the sampling site for the PEACE (Role of PElagic cAlcification and export of CarbonatE production in climate change; Harlay et al., 2010, 2011) project (PEA), the southern North Sea (sNS), Heligoland Roads (Hel), the central North Sea (NS), south of the Shetland Islands (Sh) and south of the Faroe Islands (sFI). The Western English Channel Observatory (E1), Bay of Biscay (BB) and central North Sea (NS) were all sampled twice during the cruise either on consecutive days $(\mathrm{BB}, \mathrm{NS})$ or within 9 days (E1). These resampled stations are referred to with an $a$ or $b$ to distinguish between visits (e.g. NSa, NSb). The exact positions of these resampled locations were slightly different, especially in the case of BB and NS (Table 1).

Sea surface temperatures and salinities were taken from the CTD, with mixed layer depths calculated using a temperature threshold difference of $0.5^{\circ} \mathrm{C}$ relative to surface values (Painter et al., 2010) and visually checked by examining the temperature profiles (Fig. 2). Water-column structure was examined by calculating the Brunt-Väisälä frequency $\left(N^{2}\right)$ from the density profile (Knauss, 1996):

$N^{2}=(g /$ average $\sigma t) \times(\Delta \sigma t / \Delta z)$,

where $g$ is acceleration due to gravity $\left(9.81 \mathrm{~m} \mathrm{~s}^{-2}\right)$, average $\sigma t$ is the average density over the water column at each site, $\Delta \sigma t$ is the difference in density between depth pairs and $\Delta z$ is the difference in depth. $N^{2}$ estimates the strength of the vertical density gradient.

Daily incidental irradiance $\left(\operatorname{Ed}_{[0+]}\right)$, for photosynthetically active radiation (PAR), was integrated from dawn to dusk (mol photons $\mathrm{m}^{-2} \mathrm{~d}^{-1}$ ) from the RRS Discovery $2 \pi$ PAR irradiance sensor (Skye Instruments, SKE 510). The vertical diffuse attenuation coefficient of PAR $\left(K_{\mathrm{d}}\right)$ in the water column was calculated for predawn CTD stations, with the depth of the euphotic zone $\left(Z_{\text {eup }}\right)$ calculated as the depth where $1 \%$ surface irradiance penetrates, with an 

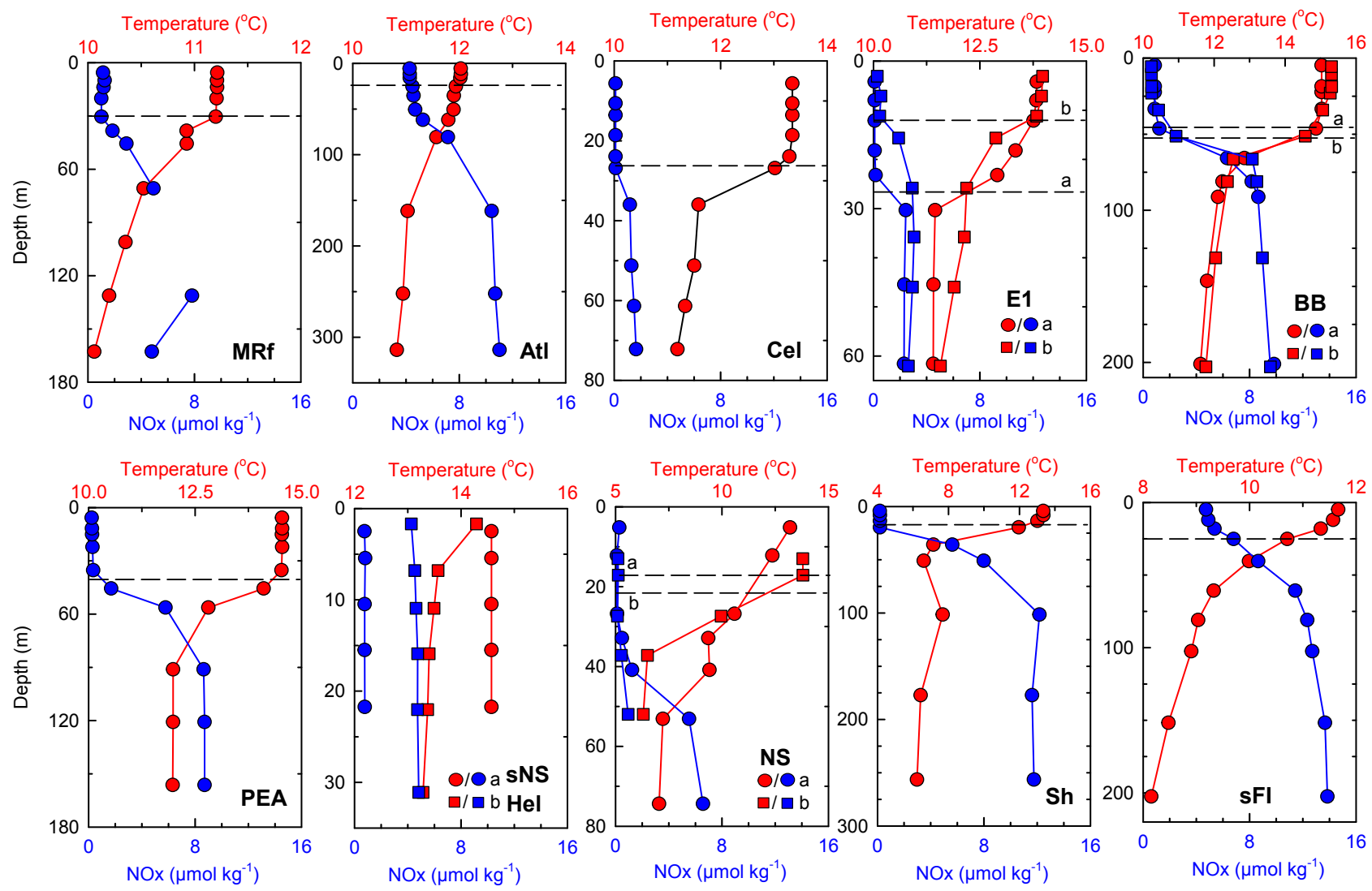

Figure 2. Vertical profiles of temperature $\left({ }^{\circ} \mathrm{C}\right)$ and nitrate + nitrite $\left(\mathrm{NO}_{\mathrm{x}}, \mu \mathrm{mol} \mathrm{N} \mathrm{kg}{ }^{-1}\right)$ over the upper water column. Dashed lines indicate mixed layer depths. Several sites were sampled twice during the cruise and these are denoted with a and b (e.g. BBa, BBb).

optical depth of 4.6. Average mixed layer PAR irradiance $\left(\bar{E} \mathrm{~d}_{[\mathrm{ML}]}\right)$, which describes the mean irradiance experienced by a particle being mixed within the mixed layer, was calculated as in Poulton et al. (2011) using a combination of $\operatorname{Ed}_{[0+]}, K_{\mathrm{d}}$ and mixed layer depth.

\subsection{Coccolithophore counts}

Samples for the determination of coccolithophore cell numbers and species identification by polarising light microscopy were collected from the five light depths. Water samples $(0.2-0.5 \mathrm{~L})$ were filtered under gentle pressure through $25 \mathrm{~mm}$ diameter, $0.8 \mu \mathrm{m}$ pore size Nuclepore ${ }^{\mathrm{TM}}$ cellulose nitrate filters, oven dried for $\sim 2-4 \mathrm{~h}$ at $50-60^{\circ} \mathrm{C}$ and stored in Petri-slides. Permanent slides of the filters were prepared immediately on-board by mounting the filters using low viscosity Norland Optical Adhesive (NOA 74) (Poulton et al., 2010). Coccolithophore cell counts and species identification were carried out under cross-polarised light using a Leitz Ortholux microscope (X1000, oil immersion). Either 300 fields of view or 300 individual cells (whichever was reached first) were counted per filter, with a minimum of 30 fields of view counted when cells were abundant. For a limited number of samples, light microscopy species identification and cell counts were verified using scanning electron microscopy (SEM) following the method outlined in Young et al. (2014).

\subsection{Primary production and calcite production}

Daily rates (dawn-dawn, $24 \mathrm{~h}$ ) of total primary production (PP) and calcite production (CP) were determined at each of the 14 productivity stations following Poulton et al. (2010). Water samples $(70 \mathrm{~mL}$ volume, 3 light, 1 formalin-killed) from the five light depths were spiked with $15-40 \mu \mathrm{Ci}$ of ${ }^{14} \mathrm{C}$-labelled sodium bicarbonate and placed in on-deck incubators chilled with surface seawater and covered with light filters (Misty-blue and Grey, LEE ${ }^{\mathrm{TM}} \mathrm{UK}$ ) to replicate the light field at depth. Formalin-killed blanks were prepared by addition of $1 \mathrm{~mL}$ of $0.2 \mu \mathrm{m}$ filtered and sodium-borate-buffered formalin solution.

Incubations were ended by filtration through $25 \mathrm{~mm}$ $0.45 \mu \mathrm{m}$ polycarbonate filters (Nuclepore ${ }^{\mathrm{TM}}$, US). Organic (PP) and inorganic (CP) carbon fixation was determined using the micro-diffusion technique (MDT) (Paasche and Brutak, 1994; Balch et al., 2000) with filters placed in Ultima Gold (Perkin-Elmer, UK) liquid scintillation cocktail and the activity on the filters determined using a Tri-Carb 2100TR Liquid Scintillation Counter. Spike activity was checked by 
removal of triplicate $100 \mu \mathrm{L}$ subsamples directly after spike addition, mixing with $200 \mu \mathrm{L}$ of $\beta$-phenylethylamine (Sigma UK), addition of Ultima Gold and liquid scintillation counting. Average relative standard deviation (RSD, standard deviation / mean $\times 100 \%$ ) of triplicate (light) total PP, measurements was $14 \%(2-47 \%)$ and $38 \%(2-93 \%)$ for triplicate (light) CP measurements. On average the formalin-killed blank represented $10 \%$ of the CP signal (range 1-63\%), with higher contributions at the base of the euphotic zone.

Daily rates (dawn-dawn, 24h) of micro-phytoplankton (herein $>10 \mu \mathrm{m}$ ) primary production were determined in parallel to total PP. Water samples ( $70 \mathrm{~mL}$ volume, 3 light) were collected from the five light depths, spiked with $3-8 \mu \mathrm{Ci}$ of ${ }^{14} \mathrm{C}$-labelled sodium bicarbonate and incubated on deck. Incubations were terminated by filtration through $25 \mathrm{~mm}$ $10 \mu \mathrm{m}$ polycarbonate filters (Nuclepore ${ }^{\mathrm{TM}}$ ), with extensive rinsing with filtered seawater to remove any potential contamination from ${ }^{14} \mathrm{C}$-labelled dissolved inorganic carbon. Finally, $15 \mathrm{~mL}$ Ultima Gold (Perkin-Elmer, UK) liquid scintillation cocktail was added and the samples counted in the Tri-Carb Liquid Scintillation Counter. Spike activity was assessed as with total PP and the average RSD of triplicate microplankton PP measurements was $19 \%$ (2-91\%). Nanoplankton PP (herein $<10 \mu \mathrm{m}$ ) was calculated as the difference between total PP and microplankton PP.

\subsection{Chlorophyll $a$, macronutrients and carbonate chemistry}

Total chlorophyll $a(\mathrm{Chl})$ was quantified according to Poulton et al. (2010), with water samples $(0.25 \mathrm{~L})$ filtered onto Whatman GF/F filters, extracted in $8 \mathrm{~mL} 90 \%$ acetone, and stored at $4{ }^{\circ} \mathrm{C}$ for $18-20 \mathrm{~h}$. Fluorescence was measured on a Turner Designs Trilogy Fluorometer, calibrated with purified chlorophyll $a$ (Sigma, UK), and drift in the fluorometer was monitored using a solid standard. Chlorophyll in the $>10 \mu \mathrm{m}$ fraction was measured on a $10 \mu \mathrm{m}$ polycarbonate filter $(0.25 \mathrm{~L})$, with $\mathrm{Chl}$ in the $<10 \mu \mathrm{m}$ fraction calculated as the difference between the two. Surface macronutrient (nitrate + nitrite, $\mathrm{NO}_{\mathrm{x}}$; phosphate, $\mathrm{PO}_{4}$; silicic acid, $\mathrm{dSi}$ ) concentrations were determined using an auto-analyser following standard protocols (Grasshoff et al., 1983).

During D366, measurements to calculate carbonate chemistry parameters were determined following two distinct protocols, one for the CTD samples and another for the bioassays.

For the CTD samples, the methodology for dissolved inorganic carbon $\left(C_{\mathrm{T}}\right)$ and total alkalinity $\left(A_{\mathrm{T}}\right)$ sampling and analysis followed Ribas-Ribas et al. (2014) and Bakker and Lee (2012), and is similar to Bakker et al. (2007). Duplicate water samples were drawn from the CTD into $250 \mathrm{~mL}$ borosilicate glass bottles following Dickson et al. (2007). CTD samples were poisoned with $50 \mu \mathrm{L}$ of a saturated mercuric chloride solution and analysed for $C_{\mathrm{T}}$ and $A_{\mathrm{T}}$ on a VINDTA 3C instrument (Marianda, Germany). These water sam- ples were then analysed for $C_{\mathrm{T}}$ by the coulometric method after Johnson et al. (1987) with two to three CRMs (certified reference material, batch 107) used for calibration per coulometric cell and CTD station. Total alkalinity measurements for CTD samples were made by potentiometric titration with a Metrohm Titrino 719S for adding acid, an ORION-Ross $\mathrm{pH}$ electrode and a Metrohm reference electrode. The precision and accuracy of both $A_{\mathrm{T}}$ and $C_{\mathrm{T}}$ analysis from the CTD was $<2 \mu \mathrm{mol} \mathrm{kg}^{-1}$.

Initial measurements for the short-term bioassays followed the sampling procedure of Dickson et al. (2007) with samples collected from CTD Niskin bottles in $250 \mathrm{~mL}$ Schott Duran borosilicate glass bottles with glass stoppers and analysed within $1 \mathrm{~h}$ of collection. Samples from the end time point of the bioassays were collected in $40 \mathrm{~mL}$ glass vials, poisoned with a saturated solution of mercuric chloride and analysed within 2 days of collection. Dissolved inorganic carbon was determined using an Apollo AS-C3 (Apollo SciTech, USA) with a precision of $<2 \mu \mathrm{mol} \mathrm{kg}{ }^{-1}$. Phosphoric acid $(10 \%)$ was used to acidify the bioassay samples, and the total amount of $\mathrm{CO}_{2}$ released was quantified using a LI-COR (7000) $\mathrm{CO}_{2}$ infrared analyser. Total alkalinity was determined for the bioassays using an Apollo AS-ALK2 (Apollo SciTech, USA) where each seawater sample was titrated with $0.1 \mathrm{M}$ hydrochloric acid (Dickson et al., 2007). All $A_{\mathrm{T}}$ samples were analysed at $25^{\circ} \mathrm{C}\left( \pm 0.1^{\circ} \mathrm{C}\right)$ using a water bath (GD120, Grant, UK) to maintain temperature. The Apollo systems were calibrated daily using CRMs (batch 109).

Calcite saturation state $\left(\Omega_{\mathrm{C}}\right), \mathrm{pH}_{\mathrm{T}}$ and $p \mathrm{CO}_{2}$ for both CTD samples and short-term bioassays were calculated from $C_{\mathrm{T}}$, $A_{\mathrm{T}}$, nutrients, temperature, salinity and pressure data using the CO2SYS $\left(\mathrm{CO}_{2}\right.$ system) program (v. 1.05; Pierrot et al., 2006), with the dissociation constants (pKs) of Mehrbach et al. (1973) as refitted by Dickson and Millero (1987).

\subsection{Nutrient and $p \mathrm{CO}_{2}$ bioassay}

Near-surface seawater $(<10 \mathrm{~m})$ was collected from three sites along the cruise track (Fig. 1) in order to conduct short-term $(48 \mathrm{~h})$ incubation experiments. These incubations are referred to as the "additional experiments" in Richier et al. (2014a) rather than the longer (96 h) "main" experiments also performed during the June 2011 cruise. We also adopt the identification scheme used in Richier et al. (2014a) to distinguish these short experiments from the longer ones by calling them 2B, 4B and 5B. Table 5 indicates the oceanographic conditions for each of the three additional bioassay experiments which were performed under precisely controlled light and temperature conditions in a purposely converted commercial refrigeration container (see Methods in Richier et al., 2014a). Briefly, 24 incubation bottles (1.25 L) were initially filled with unfiltered water containing the intact plankton communities. Seawater was supplemented with low levels of major macronutrients (nitrate, $\mathrm{NO}_{\mathrm{x}}$; phosphate, $\mathrm{PO}_{4}$; dissolved silicic acid, $\mathrm{dSi}$ ) according to an 


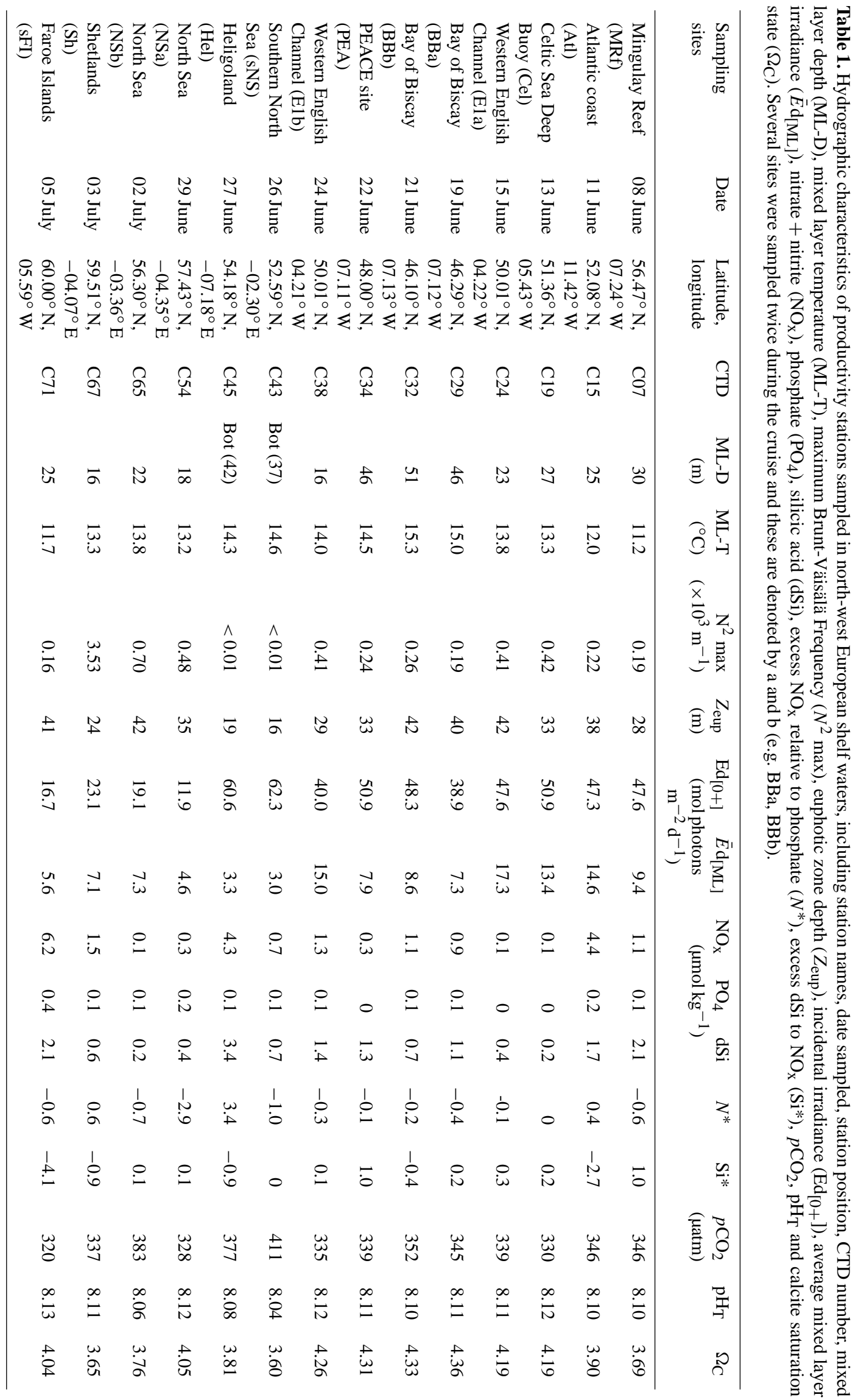


experimental design consisting of four conditions: (1) control, (2) $2 \mu \mathrm{mol} \mathrm{kg}{ }^{-1}$ added $\mathrm{NO}_{\mathrm{x}}$ and dSi, (3) $0.2 \mu \mathrm{mol} \mathrm{kg}{ }^{-1}$ and $2 \mu \mathrm{mol} \mathrm{kg}{ }^{-1}$ added $\mathrm{PO}_{4}$ and $\mathrm{dSi}$, respectively, and (4) $2 \mu \mathrm{mol} \mathrm{kg}{ }^{-1}$ added $\mathrm{NO}_{\mathrm{x}}$ and $\mathrm{dSi}$ and $0.2 \mu \mathrm{mol} \mathrm{kg}{ }^{-1}$ added $\mathrm{PO}_{4}$ (hereafter control, $+\mathrm{N},+\mathrm{P},+\mathrm{NP}$ ). A first set of triplicate bottles for each condition was kept at present-day $p \mathrm{CO}_{2}$, while a second set was adjusted to $p \mathrm{CO}_{2}$ projected for the year 2100 (target $750 \mu \mathrm{atm} \mathrm{CO}_{2}$, see Gattuso et al., 2010) (Table 5). Addition of dSi to all treatments aimed to encourage the growth of diatoms, if present, as the experimental protocol was designed to examine phytoplankton community responses to nutrient addition and $p \mathrm{CO}_{2}$ increases rather than specific phytoplankton groups.

Carbonate chemistry manipulation in the incubation bottles followed the method described in Richier et al. (2014a). Briefly, the initial carbonate chemistry in the seawater was characterised (see previous section) and subsequently manipulated in the incubation bottles using an equimolar addition of strong acid $\left(\mathrm{HCl}, 1 \mathrm{~mol} \mathrm{~kg}^{-1}\right)$ and sodium bicarbonate $\left(\mathrm{NaHCO}_{3}^{-}, 1 \mathrm{~mol} \mathrm{~kg}^{-1}\right.$ ) (Gattuso et al., 2010). In addition, three independent bottles were measured at $T_{0}$ and checked for the accuracy of the method. After $48 \mathrm{~h}$ incubation, subsamples were removed for determination of carbonate chemistry, macronutrient concentrations, chlorophyll $a$ concentrations and coccolithophore cell abundances. Subsamples were also removed and processed for determination of rates of primary production and calcite production. The methodology for all these measurements followed those detailed above for the in situ measurements.

\subsection{Data availability and statistical analysis}

All data included in the paper are available from the British Oceanographic Data Centre (BODC; www.doi.org) via Poulton (2014) for the discrete measurements of primary production and calcite production (doi:10/s8q); Richier et al. (2014b) for measurements of calcite production and ancillary data from the experimental bioassays (doi:10/s8r); and Ribas-Ribas et al. (2014b) for ancillary data (nutrients, carbonate chemistry) from the CTD casts (doi:10/thr).

Pearson product-moment correlations $(r)$ were performed in SigmaPlot (V11) to describe the correlations between coccolithophore dynamics and environmental variables. For treatment effects in the experimental bioassays one-way ANalysis Of VAriance (ANOVA) (SigmaPlot V11.0) and pairwise $t$ tests were performed (SigmaPlot V11.0). For normally distributed data, one-way ANOVA and pairwise Holm-Sidak comparisons were used, while for non-normally distributed data a Kruskal-Wallis one-way ANOVA on ranks and pairwise Dunn comparison of the ranks were used.

\section{Results}

\subsection{General hydrography}

A number of distinct hydrographic environments were sampled around the NW European Shelf, including the open ocean (BB, PEA), shelf-break (MRf, Atl, Sh, sFI), seasonally stratified (Cel, E1, NS) and fully mixed (sNS, Hel) (Figs. 1 and 2) environments. Open-ocean sites generally had the deepest mixed layers $(>45 \mathrm{~m})$, while mixed layer depths were similar for shelf-break and stratified sites $(<30 \mathrm{~m})$ and fully mixed sites were mixed to the seafloor $(\sim 40 \mathrm{~m})$ (Table 1; Fig. 2). There was a noticeable north-south gradient in mixed layer temperature of $\sim 3-4^{\circ} \mathrm{C}$ (Fig. 1a; Table 1), with sea surface temperature at oceanic stations in the Bay of Biscay $\sim 15^{\circ} \mathrm{C}$ (Fig. 2).

Mixed layer salinities were generally $>34.8$ except at the mixed sites (sNS, Hel) and off the Shetland Islands where values were 33.2 and 34.1 and as low as 30.7 , respectively (Table 1). The maximum value of the Brunt-Väisälä Frequency $\left(\mathrm{N}^{2}\right)$ occurred south of the Shetland Islands $(3.53 \times$ $\left.10^{3} \mathrm{~m}^{-1}\right)$, but it was also high $\left(0.4-0.7 \times 10^{3} \mathrm{~m}^{-1}\right)$ at stratified shelf sites including Cel, E1 and NS (Table 1). In contrast, the lowest values $\left(<0.01 \times 10^{3} \mathrm{~m}^{-1}\right)$ occurred at the fully mixed sites (sNS, Hel) and values $<0.3 \times 10^{3} \mathrm{~m}^{-1}$ were found at oceanic (BB, PEA) and shelf-break stations (MRf, Atl, sFI).

Euphotic zone depth $\left(Z_{\text {eup }}\right)$ was generally $>24 \mathrm{~m}$ and showed little variability between hydrographic environments, although the shallowest euphotic zones (16-19m) were at the fully mixed sites (sNS, Hel), likely due to sediment resuspension. The ratio of mixed layer depth to euphotic zone depth was less than 1 at almost all sampling sites (see Table 1), apart from those associated with open-ocean conditions (BB, PEA) and at MRf, indicating that the potential for cells to be mixed into sub-euphotic zone irradiance conditions was limited to oceanic sites.

When expressed as the percentage of incident irradiance (i.e. $\mathrm{Ed}_{[0+]}$ ), average mixed layer irradiance (an indication of the average irradiance experienced by cells in the mixed layer) was between 20 and $40 \%$ for shelf-break and stratified sites, whereas it was $<20 \%$ for oceanic sites (BB, PEA) and as low as $5-6 \%$ for the fully mixed sites (sNS, Hel).

Daily photon fluxes for PAR $\left(\operatorname{Ed}_{[0+]}\right)$ varied during the cruise with values $>40$ mol photons $\mathrm{m}^{-2} \mathrm{~d}^{-1}$ until 24 June (E1b), increasing to $>60$ mol photons $\mathrm{m}^{-2} \mathrm{~d}^{-1}$ during the next 3 days (sNS, Hel) before decreasing dramatically to $<24$ mol photons $\mathrm{m}^{-2} \mathrm{~d}^{-1}$ for the remainder of the cruise (NS, Sh, sFI) as a result of bad weather in the North Sea. This temporal trend in incident irradiance translated into differences in absolute mixed layer irradiance values (Table 1) that were slightly different than the percentage values.

Average mixed layer irradiances $\left(\bar{E} \mathrm{~d}_{[\mathrm{ML}]}\right)$ at shelfbreak sites varied from 9.4-14.6 mol photons $\mathrm{m}^{-2} \mathrm{~d}^{-1}$ (MRf, Atl) to 5.6-7.1 mol photons $\mathrm{m}^{-2} \mathrm{~d}^{-1}$ (Sh, sFI) and 
from 13.4-17.3 mol photons $\mathrm{m}^{-2} \mathrm{~d}^{-1}$ (Cel, E1) to 4.67.3 mol photons $\mathrm{m}^{-2} \mathrm{~d}^{-1}$ at stratified central North Sea sites. In the open ocean, average mixed layer irradiance was 7.38.6 mol photons $\mathrm{m}^{-2} \mathrm{~d}^{-1}$ (BB, PEA), while low values were found at the fully mixed sites (3.0-3.3 mol photons $\mathrm{m}^{-2} \mathrm{~d}^{-1}$ ) (Table 1).

Surface concentrations of $\mathrm{NO}_{\mathrm{x}}, \mathrm{PO}_{4}$ and dSi at the stratified shelf sites (Cel, Ela, NS) were below $0.3 \mu \mathrm{mol} \mathrm{kg}^{-1}$, $0.2 \mu \mathrm{mol} \mathrm{kg}{ }^{-1}$ and $0.4 \mu \mathrm{mol} \mathrm{kg}^{-1}$, respectively (Table 1; Fig. 2). The notable exception was on the second visit to E1 (E1b, 24 June), when surface concentrations of $\mathrm{NO}_{\mathrm{x}}$ and $\mathrm{dSi}$ were elevated relative to initial conditions, indicating a mixing event between visits. Sites near the shelf-break had higher $\mathrm{NO}_{\mathrm{x}}\left(1.1-6.2 \mu \mathrm{mol} \mathrm{kg}{ }^{-1}\right), \mathrm{PO}_{4}\left(0.1-0.4 \mu \mathrm{mol} \mathrm{kg}{ }^{-1}\right)$ and dSi $\left(0.6-2.1 \mu \mathrm{mol} \mathrm{kg}{ }^{-1}\right)$ than stratified sites on the shelf, while open-ocean sites had $\mathrm{NO}_{\mathrm{x}}$ of $\sim 0.3-1.1 \mu \mathrm{mol} \mathrm{kg} \mathrm{kg}^{-1}$, $\mathrm{PO}_{4}<0.1 \mu \mathrm{mol} \mathrm{kg}{ }^{-1}$ and dSi of $0.7-1.3 \mu \mathrm{mol} \mathrm{kg}{ }^{-1}$ (Table 1; Fig. 2). The two mixed sites on the shelf had quite different nutrient concentrations, with Hel having higher $\mathrm{NO}_{\mathrm{x}}$ (and $\mathrm{dSi}$ ) values than sNS, while the two had similar $\mathrm{PO}_{4}$ concentrations (Table 1; Fig. 2).

The value of $N^{*}$, expressed as $N^{*}=\mathrm{NO}_{\mathrm{x}}-16 \times \mathrm{PO}_{4}$ (e.g. Moore et al., 2009) was generally negative (MRf, E1, $\mathrm{BB}, \mathrm{PEA}, \mathrm{sNS}, \mathrm{NS}, \mathrm{sFI}$ ), indicating low $\mathrm{NO}_{\mathrm{x}}$ concentrations relative to $\mathrm{PO}_{4}$, apart from at Atl, Hel and Sh which indicated high $\mathrm{NO}_{\mathrm{x}}$ concentrations relative to low $\mathrm{PO}_{4}$ (Table 1). Station $\mathrm{Hel}$ had the highest positive $N^{*}$, indicating high residual $\mathrm{NO}_{\mathrm{x}}$ relative to low $\mathrm{PO}_{4}$, while station NSa had the lowest negative $N^{*}$. The value of $\mathrm{Si}^{*}$, expressed as $\mathrm{Si} *=\mathrm{dSi}-\mathrm{NO}_{\mathrm{x}}$ (e.g. Bibby and Moore, 2011), was negative at several sites (Atl, BBb, Hel, Sh, SFI), indicating low dSi concentrations relative to $\mathrm{NO}_{\mathrm{x}}$, but positive at others (MRf, Cel, E1, BBa, PEA, sNS, NS), indicating enhanced dSi concentrations relative to low $\mathrm{NO}_{\mathrm{x}}$ (Table 1). Stations MRf and PEA had the highest positive $\mathrm{Si}^{*}(1)$, indicating high residual dSi concentrations relative to nitrate, whereas stations sFI $(-4.1)$ and Atl (-2.7) had the lowest negative $\mathrm{Si}^{*}$.

Surface water $\mathrm{pH}_{\mathrm{T}}$ values varied from 8.04 to 8.13 , showing variability of less than $0.1 \mathrm{pH}$ units between productivity stations, and was lowest in the sNS (Table 1). Calcite saturation states varied from 3.60 to 4.36 , with the lowest value in the sNS and the highest values at the open-ocean stations (BB, PEA) (Table 1).

\subsection{In situ chlorophyll and primary production}

Discrete measurements of total chlorophyll (Chl) varied from $<1 \mathrm{mg} \mathrm{m}^{-3}$ to a maximum of $\sim 5 \mathrm{mg} \mathrm{m}^{-3}$ (Fig. 3). Vertical profiles of total $\mathrm{Chl}$ showed either uniform concentrations through the mixed layer and/or euphotic zone (e.g. Atl, E1, PEA) or deep maxima associated with the base of the mixed layer (e.g. Cel, Sh). Highest total Chl was found at the fully mixed Hel station and lowest Chl at the NS and BB sites (Fig. 3). Integrated euphotic zone total Chl concentrations ranged from 20.9 to $93.1 \mathrm{mg} \mathrm{m}^{-2}$ (Table 2), with generally low concentrations $\left(<30 \mathrm{mg} \mathrm{m}^{-2}\right)$ at the stratified shelf (Cel, E1, NS) and open-ocean (BB) sites, although integrated total Chl was $>60 \mathrm{mg} \mathrm{m}^{-2}$ at the open-ocean PEA site. Shelf-break sites had both moderate $\left(40-45 \mathrm{mg} \mathrm{m}^{-2}\right.$, Atl, Sh, sFI) and high (>90 $\mathrm{mg} \mathrm{m}^{-2}$ ) integrated total Chl, whereas mixed shelf sites had both low $\left(<30 \mathrm{mg} \mathrm{m}^{-2}\right.$, sNS) and high $\left(>80 \mathrm{mg} \mathrm{m}^{-2}, \mathrm{Hel}\right)$ values (Table 2$)$.

Integrated euphotic zone microplankton $(>10 \mu \mathrm{m}) \mathrm{Chl}$ varied from 2.6 to $78.0 \mathrm{mg} \mathrm{m}^{-2}$, with highest values found at the mixed Hel site (data not shown). When expressed as a percentage of total $\mathrm{Chl}$, nanoplankton $\mathrm{Chl}(<10 \mu \mathrm{m})$ contributions ranged from 8 to $97 \%$, with the lowest value found at the Hel site (Table 2). At almost all sampling sites the $<10 \mu \mathrm{m}$ fraction was the dominant contributor to total $\mathrm{Chl}$, as shown in the scatter plot of total and microplankton integrated Chl (Fig. 4a). The exceptions were at the Hel site where microplankton Chl contributed $92 \%$, and at E1b where it was $55 \%$ (Fig. 4a).

Discrete measurements of total primary production (PP) varied from $<0.1$ to $6 \mathrm{mmol} \mathrm{C} \mathrm{m}^{-3} \mathrm{~d}^{-1}$, with low values generally at the base of the euphotic zone and highest rates at the Hel site (Fig. 3). In general, the vertical profiles of total PP (Fig. 3) showed high values in upper waters and decreased with depth (irradiance), with little or no evidence of sub-surface productivity maxima. Integrated euphotic zone total PP ranged from 45.2 to $229.9 \mathrm{mmol} \mathrm{C} \mathrm{m}^{-2} \mathrm{~d}^{-1}$ (Table 2), with values between 45.2 and $128.6 \mathrm{mmol} \mathrm{C} \mathrm{m}^{-2} \mathrm{~d}^{-1}$ in stratified shelf sites (Cel, E1, NS) and between 73.5 and $151.6 \mathrm{mmol} \mathrm{C} \mathrm{m}^{-2} \mathrm{~d}^{-1}$ in shelf-break sites (MRf, Atl, Sh, sFI). Open-ocean sites (BB, PEA) had integrated total PP between 88.1 and $229.9 \mathrm{mmol} \mathrm{C} \mathrm{m}^{-2} \mathrm{~d}^{-1}$ and the mixed shelf sites (sNS, Hel) had values between 89.5 and 197.9 mmol C m$^{-2} \mathrm{~d}^{-1}$ (Table 2).

Integrated total $\mathrm{Chl}$ and total PP were significantly positively correlated $(r=0.76, p<0.005, n=14)$. Integrated microplankton $(>10 \mu \mathrm{m}) \mathrm{PP}$ varied from 3.8 to $169.3 \mathrm{mmol} \mathrm{C} \mathrm{m}^{-2} \mathrm{~d}^{-1}$, with the highest value at the Hel site (data not shown). When expressed as a percentage of total $\mathrm{PP}$, nanoplankton PP ranged from 14 to $96 \%$, with the lowest contribution at the Hel site (Table 2). At almost all the productivity sites, the $<10 \mu \mathrm{m}$ fraction was the dominant contributor to total PP (Table 2), as shown in the scatter plot of total and nanoplankton PP (Fig. 4b). The exception, again, was the Hel site where the microplankton fraction dominated PP (Fig. 4b).

\subsection{In situ calcite production, coccolithophore abundance and cell-specific calcification}

Discrete measurements of calcite production (CP) varied from $<10$ to $825 \mu \mathrm{mol} \mathrm{C} \mathrm{m}^{-3} \mathrm{~d}^{-1}$, with low rates generally found at the base of the euphotic zone (Fig. 5). Vertical profiles of CP generally showed high rates near to the surface at the top of the euphotic zone, and often these then decreased with increasing depth and were associated with decreasing 
Table 2. Euphotic zone integrals of total chlorophyll $\left(\mathrm{Chl}_{\text {tot }}\right)$, total primary production $\left(\mathrm{PP}_{\text {tot }}\right)$, calcite production $(\mathrm{CP})$, ratio of calcite production to primary production $(\mathrm{CP}: \mathrm{PP})$, nanoplankton contributions to $\mathrm{Ch}_{\text {tot }}$ and $\mathrm{PP}_{\text {tot }}$ and coccolithophore contributions to $\mathrm{PP}$ tot and $\mathrm{PP}_{\text {nano }}$

\begin{tabular}{|c|c|c|c|c|c|c|c|c|c|}
\hline \multirow{2}{*}{$\begin{array}{l}\text { Sampling } \\
\text { site }\end{array}$} & \multirow[t]{2}{*}{ CTD } & \multirow{2}{*}{$\begin{array}{l}\mathrm{Chl}_{\text {tot }} \\
\left(\mathrm{mg} \mathrm{m}^{-2}\right)\end{array}$} & \multirow{2}{*}{\multicolumn{2}{|c|}{$\begin{array}{l}\mathrm{PP}_{\text {tot }} \quad \mathrm{CP} \\
(\mathrm{mmol} \mathrm{C} \mathrm{m} \\
\left.-2 \mathrm{~d}^{-1}\right)\end{array}$}} & \multirow{2}{*}{$\begin{array}{l}\mathrm{CP}: \mathrm{PP}_{\text {tot }} \\
(\mathrm{mol}: \mathrm{mol})\end{array}$} & \multicolumn{2}{|c|}{$\begin{array}{c}\text { Nanoplankton } \\
\text { contributions }(\%)\end{array}$} & \multicolumn{2}{|c|}{$\begin{array}{l}\text { Coccolithophore } \\
\text { contributions }(\%)\end{array}$} \\
\hline & & & & & & $\mathrm{Chl}_{\text {tot }}$ & $\mathrm{PP}_{\text {tot }}$ & $\mathrm{PP}_{\text {tot }}$ & $\mathrm{PP}_{\text {nano }}$ \\
\hline MRf & $\mathrm{C} 07$ & 93.1 & 151.6 & 2.7 & 0.02 & 97 & 96 & 1 & 1 \\
\hline Atl & $\mathrm{C} 15$ & 40.7 & 127.9 & 4.0 & 0.03 & 91 & 95 & 2 & 2 \\
\hline $\mathrm{Cel}$ & C19 & 28.5 & 128.6 & 0.7 & 0.01 & ND & 77 & $<1$ & $<1$ \\
\hline E1a & $\mathrm{C} 24$ & 22.7 & 68.0 & 6.3 & 0.09 & 67 & 61 & 6 & 11 \\
\hline $\mathrm{BBa}$ & $\mathrm{C} 29$ & 26.2 & 88.1 & 0.6 & 0.01 & 82 & 87 & $<1$ & 1 \\
\hline $\mathrm{BBb}$ & C32 & 29.1 & 122.8 & 1.5 & 0.01 & 64 & 85 & 1 & 1 \\
\hline PEA & C34 & 64.5 & 229.9 & 1.2 & 0.01 & 92 & 93 & $<1$ & $<1$ \\
\hline E1b & C38 & 30.7 & 95.2 & 3.7 & 0.04 & 45 & 71 & 3 & 4 \\
\hline sNS & $\mathrm{C} 43$ & 29.7 & 89.5 & 0.6 & 0.01 & 85 & 93 & $<1$ & 1 \\
\hline Hel & $\mathrm{C} 45$ & 85.0 & 197.9 & 9.6 & 0.05 & 8 & 14 & 3 & 23 \\
\hline $\mathrm{NSa}$ & C54 & 25.8 & 52.5 & 1.8 & 0.03 & 90 & 83 & 2 & 3 \\
\hline $\mathrm{NSb}$ & C65 & 20.9 & 45.2 & 1.2 & 0.03 & 78 & 92 & 2 & 2 \\
\hline Sh & C67 & 44.4 & 73.5 & 2.1 & 0.03 & 82 & 88 & 2 & 2 \\
\hline sFI & C71 & 39.3 & 104.2 & 0.7 & 0.01 & 89 & 80 & $<1$ & 1 \\
\hline
\end{tabular}

ND is not determined.
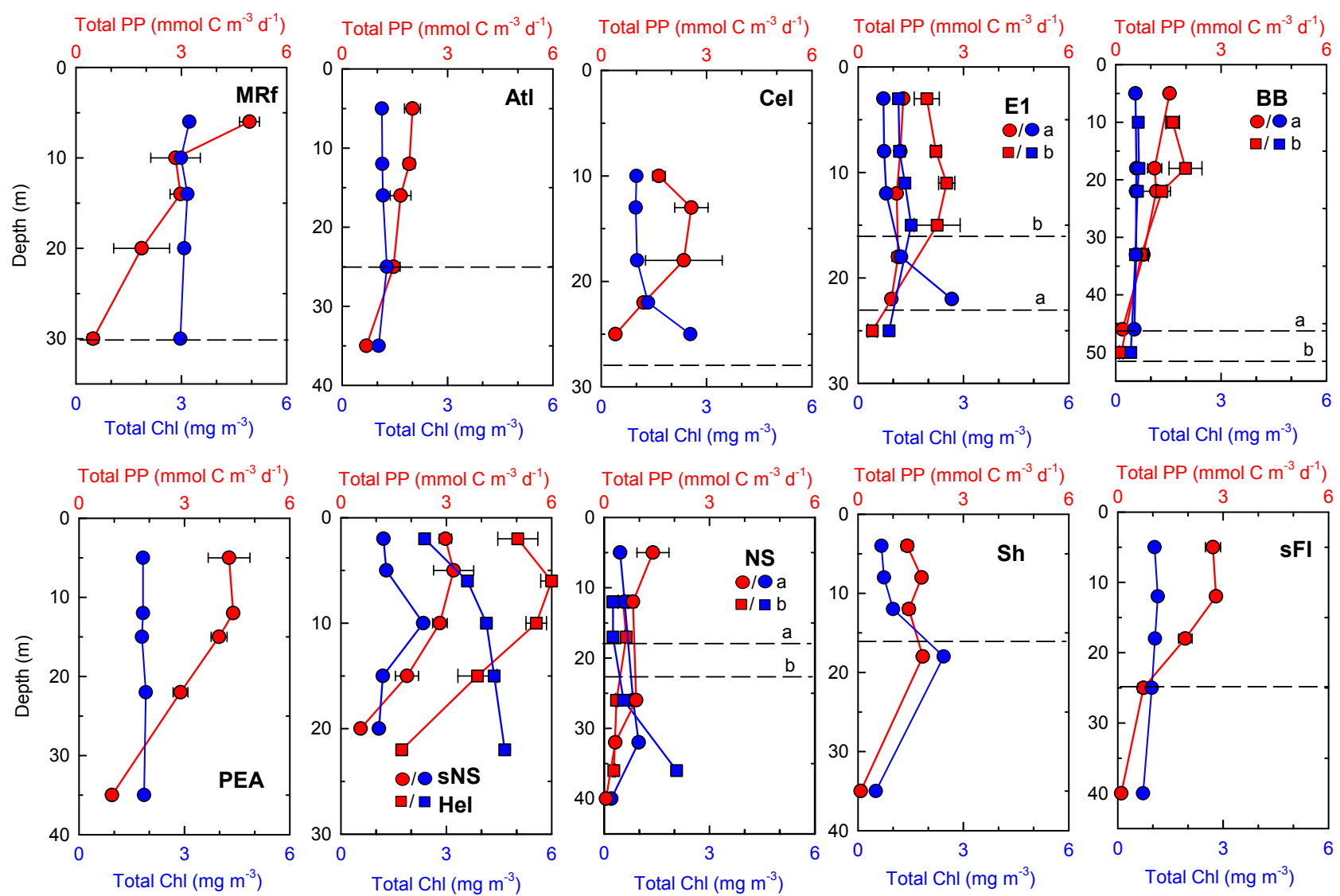

Figure 3. Vertical profiles of total primary productivity (total PP, $\mathrm{mmol} \mathrm{C} \mathrm{m}^{-3} \mathrm{~d}^{-1}$ ) and total chlorophyll (total $\mathrm{Chl}, \mathrm{mg} \mathrm{m}^{-3}$ ) over the euphotic zone. Dashed lines indicate mixed layer depths. 

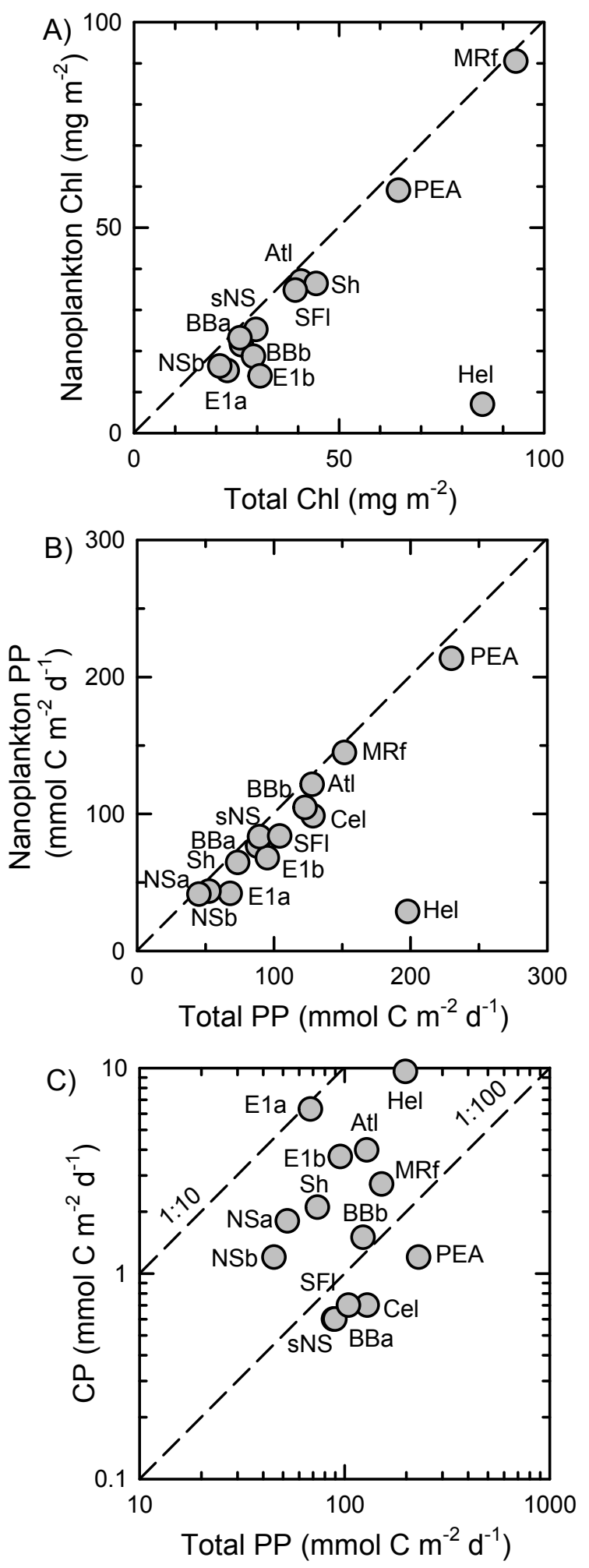

Figure 4. Scatter plots of integrated (A) total $\mathrm{Chl}$ and nanoplankton $(<10 \mu \mathrm{m}) \mathrm{Chl}\left(\mathrm{mg} \mathrm{m}^{-2}\right)$, (B) total PP and nanoplankton $(<10 \mu \mathrm{m})$ $\mathrm{PP}\left(\mathrm{mmol} \mathrm{C} \mathrm{m}{ }^{-2} \mathrm{~d}^{-1}\right)$, and $(\mathbf{C})$ calcite production $(\mathrm{CP})$ and total $\mathrm{PP}$ $\left(\mathrm{mmol} \mathrm{C} \mathrm{m}{ }^{-2} \mathrm{~d}^{-1}\right)$. Dashed lines in $(\mathbf{A})$ and $(\mathbf{B})$ indicate the $1: 1$ line, while dashed lines in $(\mathbf{C})$ indicate ratios of $1: 10$ and $1: 100$. irradiance, with no evidence of significant sub-surface peaks in CP (Fig. 5). Highest discrete measurements of $\mathrm{CP}$ were found in surface waters at $\mathrm{Hel}\left(>700 \mu \mathrm{mol} \mathrm{C} \mathrm{m}{ }^{-3} \mathrm{~d}^{-1}\right)$ and the lowest were found in the stratified shelf waters at Cel.

Integrated euphotic zone $\mathrm{CP}$ varied from 0.6 to $9.6 \mathrm{mmol} \mathrm{C} \mathrm{m}^{-2} \mathrm{~d}^{-1}$, with highest integrated $\mathrm{CP}$ at Hel (Table 2; Fig. 4c). Apart from the Atl and E1 sites, integrated $\mathrm{CP}$ was less than $3 \mathrm{mmol} \mathrm{C} \mathrm{m}^{-2} \mathrm{~d}^{-1}$ for the other sampling sites. The ratio of integrated $\mathrm{CP}$ to $\mathrm{PP}$ varied from $<0.01$ to 0.09 , indicating that $\mathrm{CP}$ never contributed more than $10 \%$ to the total carbon fixation $(=\mathrm{CP}+$ total PP). Highest $\mathrm{CP}$ to $\mathrm{PP}$ ratios were observed at $\mathrm{E} 1 \mathrm{a}$, whereas the site with the highest integrated $\mathrm{CP}(\mathrm{Hel})$ had a CP : PP ratio of only 0.05 (i.e. despite the highest discrete and integrated $\mathrm{CP}$ values at $\mathrm{Hel}, \mathrm{CP}$ was only $5 \%$ of total carbon fixation) (Table 2; Fig. 4c). CP showed no significant $(p>0.1)$ correlations with total Chl or PP, but did show significant $(p<0.001)$ relationships with microplankton $\mathrm{Chl}(r=0.80, n=13)$ and microplankton PP $(r=0.79, n=14)$.

Discrete measurements of coccolithophore abundances ranged from $<1$ cell mL ${ }^{-1}$ (Cel) to 898 cells mL $\mathrm{mL}^{-1}$ (Hel) across the 14 sampling sites (Fig. 5), and this abundance pattern agreed well with cell numbers averaged over the upper euphotic zone $(<30 \mathrm{~m})$ (Table 3$)$. Vertical profiles of coccolithophore cell numbers were slightly more variable with depth than CP profiles, although most profiles showed uniform or decreasing numbers with depth (Fig. 5). Emiliania huxleyi was the dominant species at most sites, typically representing more than $70 \%$ of total cell numbers at all but a few sites (Cel, PEA) (Table 3). Other coccolithophore species present included Gephyrocapsa muellerae, Syracosphaera spp., Coronosphaera mediterranea, Acanthoica quattrospina, Coccolithus pelagicus, Braarudosphaera bigelowii, Calcidiscus leptoporus and Algirosphaera robusta (Young et al., 2014). Offshore at the BB and PEA stations, E. huxleyi dominance was reduced ( $<80 \%$ total cells), with either G. muellerae, (BB) or Syracosphaera spp. (PEA) becoming a significant component of the assemblage.

Dividing CP by cell numbers allows calculation of cell specific rates (cell-CF), an index of cellular calcification by the species present (Poulton et al., 2010). Discrete measurements of cell-CF were generally $<1.5$ pmol Ceell ${ }^{-1} \mathrm{~d}^{-1}$ apart from at Cel where they

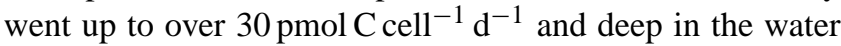
column at BB where they went up to $4 \mathrm{pmol} \mathrm{Cell}^{-1} \mathrm{~d}^{-1}$ (Fig. 6). In the case of Cel, light microscope cell counts were at the limit of detection $\left(\sim 1 \mathrm{~mL}^{-1}\right)$ despite significant CP. Examination of surface SEM images from Cel observed $\sim 26$ cells $\mathrm{mL}^{-1}$ (A. quattrospina, Syracosphaera borealis and an unidentified holococcolithophorid), which leads to a median recalculated cell-CF value of $1.5 \mathrm{pmol} \mathrm{C}$ cell $^{-1} \mathrm{~d}^{-1}$ (Table 3). At the BB stations, G. muellerae represented $20-30 \%$ of the total coccolithophore community in surface waters, and in the case of $\mathrm{BBb}$ it increased to equal numbers with $E$. huxleyi at depths where cell-CF was 
Table 3. Upper euphotic zone averages ( \pm sd) of coccolithophore cellular abundances, E. huxleyi relative abundance, calcite production (CP), and cell-normalised calcification rate (cell-CF).

\begin{tabular}{llllll}
\hline Station & CTD & $\begin{array}{l}\text { Coccolithophore } \\
\text { abundance } \\
(\text { cells mL }\end{array}$ & $\begin{array}{l}\text { Relative } \\
\text { E. huxleyi } \\
\text { abundance } \\
(\%)\end{array}$ & $\begin{array}{l}\text { CP } \\
(\mu \mathrm{mol} \mathrm{C} \\
\left.\mathrm{m}^{-3} \mathrm{~d}^{-1}\right)\end{array}$ & $\begin{array}{l}\text { Cell-CF } \\
(\mathrm{pmolC} \\
\left.\text { cell }^{-1} \mathrm{~d}^{-1}\right)\end{array}$ \\
\hline MRf & C07 & $225(46)$ & $100(0)$ & $120(22)$ & $0.5(0.1)$ \\
Atl & C15 & $629(18)$ & $99.6(0.4)$ & $131(35)$ & $0.2(0.1)$ \\
Cel & C19 & $1(0)[26]^{*}$ & $0(0)$ & $39(12)$ & $39(12)[1.5]^{*}$ \\
E1a & C24 & $630(69)$ & $100(-)$ & $312(13)$ & $0.5(0.01)$ \\
BBa & C29 & $35(12)$ & $75.6(5.4)$ & $18(6)$ & $0.6(0.3)$ \\
BBb & C32 & $26(3)$ & $74.6(9.6)$ & $38(5)$ & $1.5(0.3)$ \\
PEA & C34 & $114(18)$ & $60(15.6)$ & $46(4)$ & $0.4(0.1)$ \\
E1b & C38 & $671(31)$ & $100(0)$ & $197(25)$ & $0.3(0.01)$ \\
SNS & C43 & $41(13)$ & $99.7(0.1)$ & $43(20)$ & $1.0(0.2)$ \\
Hel & C45 & $818(88)$ & $100(-)$ & $665(139)$ & $0.8(0.1)$ \\
NSa & C54 & $376(173)$ & $100(-)$ & $54(17)$ & $0.2(0.1)$ \\
NSb & C65 & $231(0)$ & $100(-)$ & $39(11)$ & $0.2(0.01)$ \\
Sh & C67 & $499(185)$ & $99.4(4.2)$ & $60(20)$ & $0.1(0.1)$ \\
SFI & C71 & $90(20)$ & $99.5(10.7)$ & $20(13)$ & $0.2(0.2)$ \\
\hline
\end{tabular}

* Values based on SEM counts (Poulton, unpublished). ND is not determined.
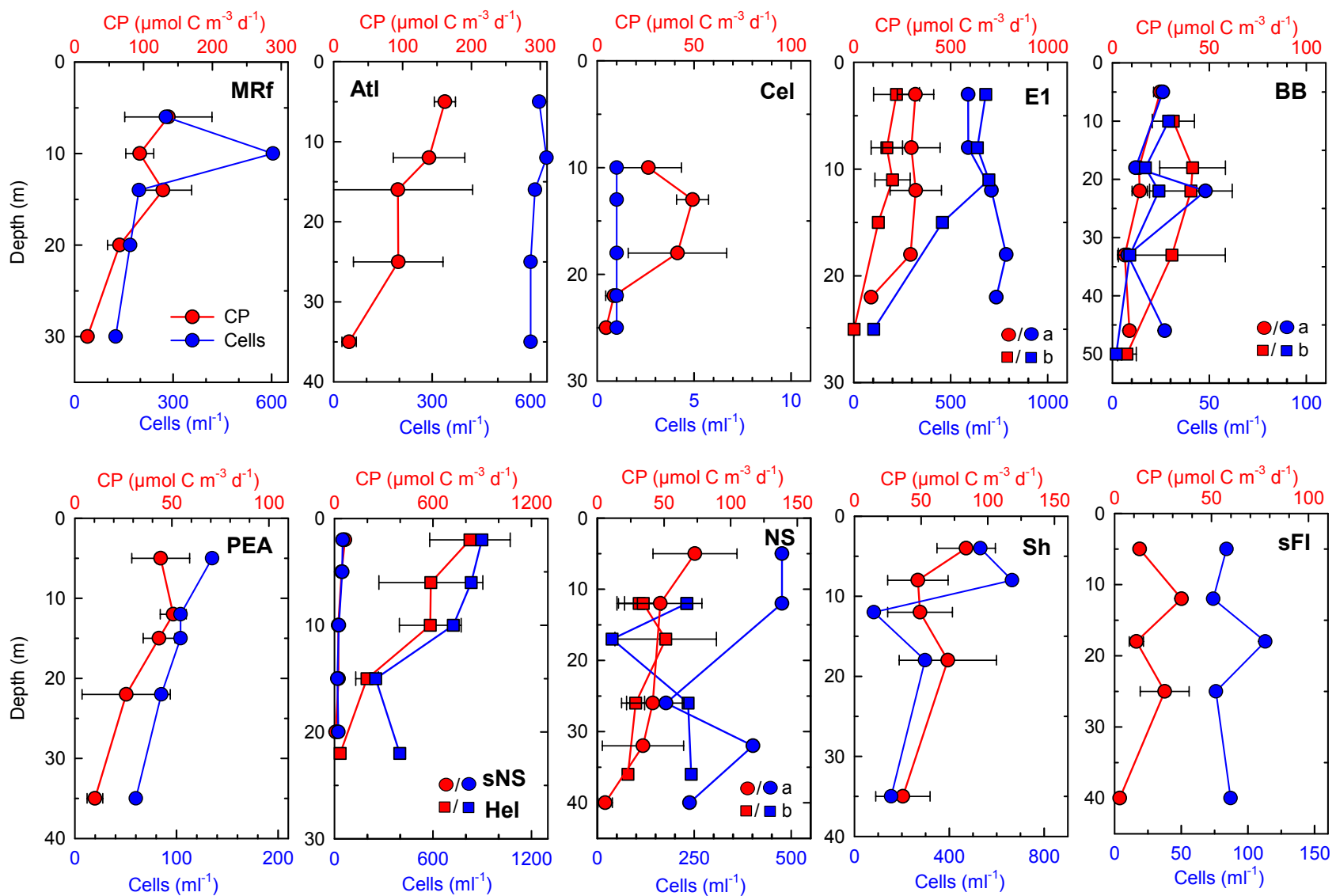

Figure 5. Vertical profiles of calcite production $\left(\mathrm{CP}, \mu \mathrm{mol} \mathrm{C} \mathrm{m}^{-3} \mathrm{~d}^{-1}\right)$ and coccosphere abundance $\left(\right.$ Cells, $\left.\mathrm{mL}^{-1}\right)$ over the euphotic zone. 

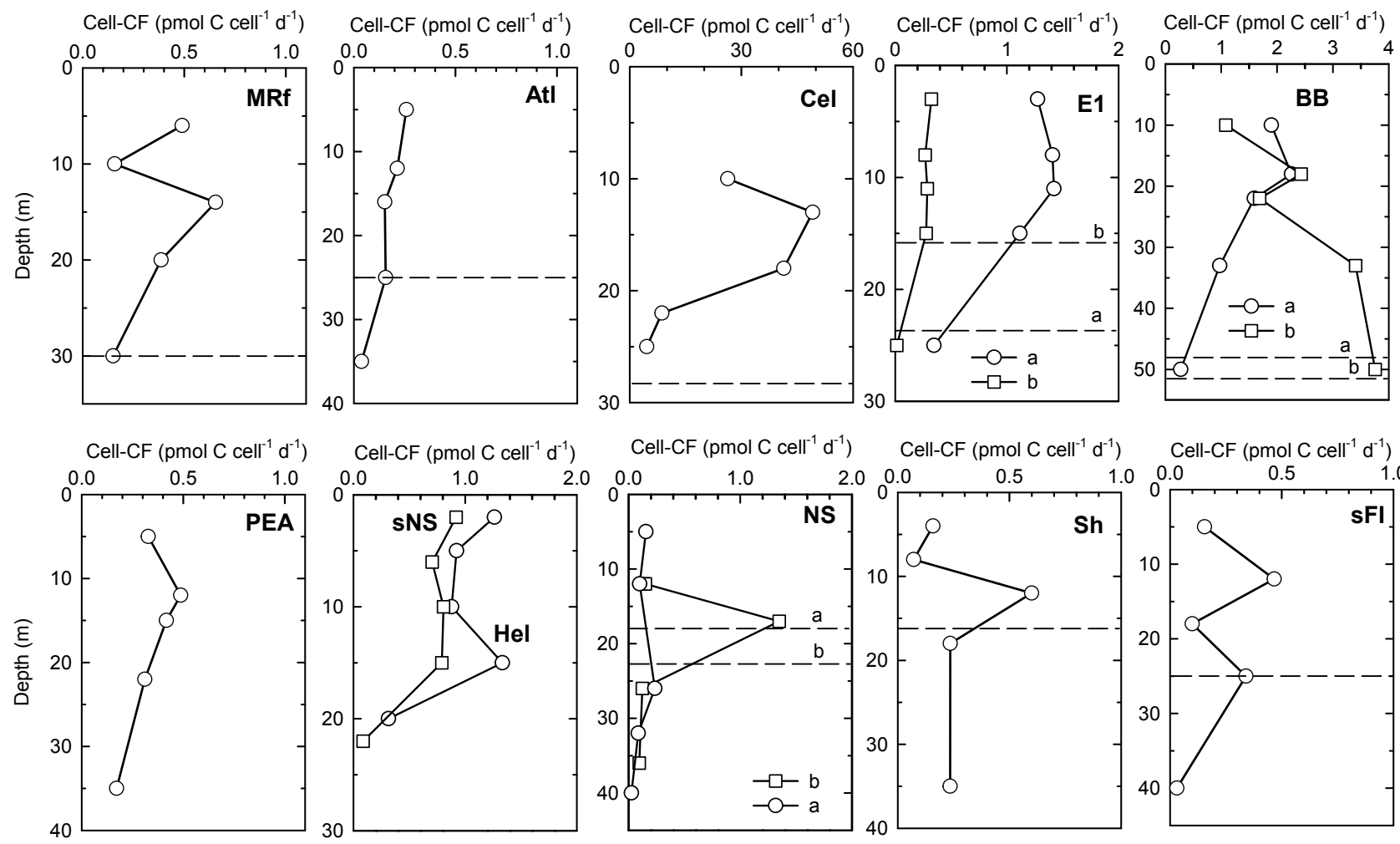

Figure 6. Vertical profiles of cell-normalised calcite production (cell-CF, pmol C cell ${ }^{-1} \mathrm{~d}^{-1}$ ) over the euphotic zone. Dashed line indicates mixed layer depth (ML-D).

$>3$ pmol Ccell ${ }^{-1} \mathrm{~d}^{-1}$ (Fig. 6). The vertical profiles of cell$\mathrm{CF}$ generally showed either uniform or slight decreases with depth, with the notable exception of BBb where it increased below $22 \mathrm{~m}$. Average cell-CF over the upper euphotic zone $(<30 \mathrm{~m})$ (Table 3$)$ generally agreed well with the vertical profiles (Fig. 5), ranging from 0.1 to $1.5 \mathrm{pmol} \mathrm{Cell}^{-1} \mathrm{~d}^{-1}$ at most sites.

\subsection{Co-variability of in situ data with environmental factors}

Statistical comparisons (Pearson product-moment correlations, $r$ ) were made between environmental factors (Table 1) and various coccolithophore metrics: $\mathrm{CP}$, coccolithophore abundance, E. huxleyi relative abundance and cell-CF. These statistical comparisons were performed at four levels: (a) for all sampling stations (apart from $\mathrm{Cel}$ ), (b) for stratified stations only (all apart from Cel, sNS and Hel), (c) for stations where E. huxleyi was dominant ( $>70 \%$ of total cells) only (see Table 3), and (d) for stations where E. huxleyi was dominant apart from Hel. Table 4 includes a summary of the statistically significant $(p<0.01)$ correlations found.

In the case of all sampling stations, significant correlations were found between both integrated and mixed layer average $\mathrm{CP}$ and $N^{*}$, between cell-CF and mixed layer depth (MLD) and between the relative abundance of E. huxleyi and $\Omega_{\mathrm{C}}$
(Table 4). The negative correlation between E. huxelyi relative abundance and $\Omega_{\mathrm{C}}$ was the only significant correlation found between a parameter of the carbonate chemistry and in situ coccolithophore dynamics (Table 4). When only the stations which were stratified (i.e. not including Cel, sNS and Hel) were examined, positive correlations were found between mixed layer average irradiance $\left(\bar{E} \mathrm{~d}_{[\mathrm{ML}]}\right)$ and integrated $\mathrm{CP}$, as well as with mixed layer average $\mathrm{CP}$ and coccolithophore abundance (Table 4). Stratified stations had negative correlations between ML-D, coccolithophore abundance and E. huxleyi relative abundance, whereas a positive correlation described the relationship between ML-D and cell-CF. Stratified stations also showed a negative correlation with the ratio of ML-D to euphotic zone depth $\left(Z_{\text {eup }}\right)$.

Consideration of stations where $E$. huxleyi dominated (i.e. not $\mathrm{Cel}, \mathrm{BBa}, \mathrm{BBb}, \mathrm{PEA}$ ) again showed positive correlations with $N^{*}$ for integrated $\mathrm{CP}$ and mixed layer average $\mathrm{CP}$, as well as positive correlations between cell-CF and ML$\mathrm{D}$, the ratio of ML-D to $Z_{\text {eup }}$, and surface irradiance $\left(\mathrm{Ed}_{[0+]}\right)$ (Table 4). If the Hel station is then removed from this analysis, relationships with $N^{*}$ disappear and strong correlations occur between $\bar{E} \mathrm{~d}_{[\mathrm{ML}]}$ and integrated $\mathrm{CP}$, mixed layer $\mathrm{CP}$ and coccolithophore (E. huxleyi) abundance. Also, the correlations between cell-CF and ML-D, ML-D : $Z_{\text {eup }}$ and $\mathrm{Ed}_{[0+]}$ remain when the Hel station is not included in the analysis (Table 4). Hence, the Hel site, with its extreme values of 
$N^{*}$ and $\bar{E} \mathrm{~d}_{[\mathrm{ML}]}$, strongly influences these relationships and when removed from the analysis reveals strong relationships between CP and irradiance. Furthermore, cell-CF correlates with ML-D in all cases (Table 4), but it is only when the offshore stations where E. huxleyi is not dominant are removed from the analysis that relationships between cell-CF, incidental irradiance $\left(\operatorname{Ed}_{[0+]}\right)$ and the ratio of ML-D to $Z_{\text {eup }}$ become significant.

\subsection{Nutrient and $p \mathrm{CO}_{2}$ bioassays}

The results from the short-term $(48 \mathrm{~h})$ nutrient and $p \mathrm{CO}_{2}$ bioassays are summarised in Fig. 7, which shows $\mathrm{CP}$, coccolithophore cell abundances and cell-CF for the three experiments. Carbonate chemistry $\left(p \mathrm{CO}_{2}, \mathrm{pH}_{\mathrm{T}}, \Omega_{\mathrm{C}}\right)$ and nutrient and total $\mathrm{Chl}$ concentrations in the bioassays are presented in Table 5. Additional variables $\left(C_{\mathrm{T}}, A_{\mathrm{T}}\right.$, salinity, temperature and depth) are presented in Richier et al. (2014a). $p \mathrm{CO}_{2}$ treatments included an ambient control and a targeted increase to $\sim 750 \mu \mathrm{atm}$, whereas nutrient amendments included a control, an $\mathrm{NO}_{\mathrm{x}}$ addition $(+\mathrm{N})$, a $\mathrm{PO}_{4}$ addition $(+\mathrm{P})$ and a combined $\mathrm{NO}_{\mathrm{x}}$ and $\mathrm{PO}_{4}$ addition (+NP) (see Sect. 2). Pairwise $t$ tests were used to test differences between ambient and $750 \mu$ atm treatments and one-way ANOVAs followed by pairwise $t$ tests were used to examine nutrient treatment effects (Fig. 7; see Sect. 2).

The coccolithophore species composition for the three nutrient and $p \mathrm{CO}_{2}$ bioassays differed between experiments. The initial coccolithophore community in the first bioassay (Bay of Biscay) was similar to in situ samples with a rough 70 : 30 percentage split between E. huxleyi and G. muellerae (SEM counts; Young unpublished). The first bioassay also had the lowest initial cell abundance $\left(15\right.$ cells $\mathrm{mL}^{-1}$, dashed line on Fig. 7). In contrast, the second and third bioassays had monospecific coccolithophore communities of $E$. huxleyi at the initial time point and generally had relatively higher cell densities at both the initial time point ( 146 cells $\mathrm{mL}^{-1}$ and 112 cells $\mathrm{mL}^{-1}$, respectively) and after $48 \mathrm{~h}$ ( $>300$ cells mL ${ }^{-1}$ and $>150$ cells $\mathrm{mL}^{-1}$, respectively) (Fig. 7). Unfortunately, no data is available on the relative species composition in these bioassays at the end of the incubations.

In the first bioassay (Bay of Biscay), initial and ambient $p \mathrm{CO}_{2}$ levels were very similar (340 $\mu \mathrm{atm}$ and $330-341 \mu \mathrm{atm}$, respectively), as were $\mathrm{pH}_{\mathrm{T}}$ values $(\sim 8.1)$ and $\Omega_{\mathrm{C}}(4.4$ and 4.3-4.5) (Table 5). Manipulation of $p \mathrm{CO}_{2}$ levels led to a decrease in $\mathrm{pH}_{\mathrm{T}}$ by $0.2-0.3$ units between ambient and the $750 \mu$ atm target $p \mathrm{CO}_{2}$ level at the end of the experiment and a rough halving of $\Omega_{\mathrm{C}}$ to values $\sim 2.6-2.7$, while nutrient additions showed little drawdown over the $48 \mathrm{~h}$ of the extra $2 \mu \mathrm{mol} \mathrm{kg}{ }^{-1}$ of $\mathrm{NO}_{\mathrm{x}}$ or $\mathrm{dSi}$, or $0.2 \mu \mathrm{mol} \mathrm{kg}^{-1}$ of $\mathrm{PO}_{4}$ (Table 5). Total $\mathrm{Chl}$ was consistently higher by a factor of 2-3 between ambient and the high $p \mathrm{CO}_{2}$ levels (Table 5). A similar decrease in nutrient drawdown and biomass in response to high $p \mathrm{CO}_{2}$ was also observed after $48 \mathrm{~h}$ of incubation in a bioassay experiment (E3) set up at the same location (Richier et al., 2014a). Significantly ( $p<0.05$ ) higher CP occurred in ambient treatments relative to the high $p \mathrm{CO}_{2}$ treatment for all nutrient treatments apart from the $+\mathrm{N}$ treatment (Fig. 7a). A significant difference $(p<0.05)$ in cell numbers between ambient and high $p \mathrm{CO}_{2}$ was only observed in the $+\mathrm{NP}$ treatment, while a significant $(p<0.05)$ difference in terms of cell-CF was only evident in the $+\mathrm{P}$ treatment (Fig. 7a). No significant differences were detected in one-way ANOVAs for the different nutrient treatments at either $\mathrm{CO}_{2}$ level for $\mathrm{CP}\left(p=0.95\right.$ for ambient, $p=0.82$ for $750 \mu$ atm $\left.\mathrm{CO}_{2}\right)$, cell numbers $(p=0.95$ and $p=0.09$, respectively) or cell-CF ( $p=0.25$ and $p=0.41$, respectively).

For the second bioassay (northern North Sea), carbonate chemistry differences between initial, ambient and the $750 \mu$ atm targeted $p \mathrm{CO}_{2}$ level were very similar to the Bay of Biscay experiment: with a $\sim 0.3$ unit decrease in $\mathrm{pH}_{\mathrm{T}}$ and a rough halving of $\Omega_{\mathrm{C}}(2.2-2.3$ versus 4.0-4.1; Table 5). In the nutrient manipulated treatments, there was very little drawdown in terms of $\mathrm{NO}_{\mathrm{x}}, \mathrm{PO}_{4}$ or dSi over the $48 \mathrm{~h}$ of the incubation, apart from in the ambient $+\mathrm{NP}$ treatment, where $\mathrm{NO}_{\mathrm{x}}$ concentrations were reduced to $1.3 \mu \mathrm{mol} \mathrm{N} \mathrm{kg}{ }^{-1}$ and $\mathrm{PO}_{4}$ concentrations to $0.1 \mu \mathrm{mol} \mathrm{\textrm {Pg } ^ { - 1 }}$ relative to the additions (Table 5). Total Chl concentrations were $\sim 30-40 \%$ higher in the ambient treatments relative to the initial and $750 \mu \mathrm{atm}$ target $p \mathrm{CO}_{2}$ treatments. Here again, nutrient consumption and biomass followed the same trend after a $48 \mathrm{~h}$ incubation period in the $96 \mathrm{~h}$ main bioassay set up in a similar area (Richier et al., 2014a). In terms of CP, pairwise $t$ tests found significant $(p<0.005)$ differences between $p \mathrm{CO}_{2}$ levels in both the $+\mathrm{N}$ and $+\mathrm{NP}$ treatments (Fig. 7b). No significant differences between $p \mathrm{CO}_{2}$ treatments were observed in terms of cell numbers; however, there were significant differences in cell-CF in the control treatments $(p<0.05)$ and $+\mathrm{N}$ treatment $(p<0.005)$. The second bioassay also showed a strong nutrient response under ambient conditions in $\mathrm{CP}$, with significantly $(p<0.05)$ increased $\mathrm{CP}$ in the $+\mathrm{NP}$ treatments relative to the controls at ambient $p \mathrm{CO}_{2}$ (Fig. 7b). No significant differences in terms of nutrient treatments were observed (one-way ANOVAs) at either $p \mathrm{CO}_{2}$ level for either cell abundances ( $p=0.34$ for ambient, $p=0.79$ for $750 \mu \mathrm{atm})$ or cell-CF ( $p=0.06$ and $p=0.22$, respectively).

In the third bioassay (Norwegian Trench), carbonate chemistry differences between initial, ambient and the $750 \mu$ atm targeted $p \mathrm{CO}_{2}$ level were similar to the other experiments, with a $\sim 0.3$ unit decrease in $\mathrm{pH}_{\mathrm{T}}$ and a rough halving of $\Omega_{C}$ (2.1 versus 3.6-3.9; Table 5). Nutrient drawdown in the third experiment occurred in both the ambient and $750 \mu \mathrm{atm} p \mathrm{CO}_{2}$ treatments, with similar decreases of $\mathrm{NO}_{\mathrm{x}}$ and $\mathrm{PO}_{4}$ independent of $p \mathrm{CO}_{2}$ treatment in the $+\mathrm{N}$ and $+\mathrm{P}$ treatments. In contrast, in the $+\mathrm{NP}$ treatments, at both $p \mathrm{CO}_{2}$ levels, there were larger decreases of $\mathrm{NO}_{\mathrm{x}}\left(\sim 0.8-1.0 \mu \mathrm{mol} \mathrm{N} \mathrm{kg}{ }^{-1}\right)$ than in the single-nutrient treatments $\left(\sim 0.4-0.6 \mu \mathrm{mol} \mathrm{N} \mathrm{kg}^{-1}\right)$. Total $\mathrm{Chl}$ was higher in $+\mathrm{N}$ and $+\mathrm{NP}$ treatments relative to the control and $+\mathrm{P}$ 
Table 4. Summary of statistically significant $(p<0.01)$ correlations between coccolithophore dynamics and environmental conditions across different sets of sampling stations.

\begin{tabular}{|c|c|c|}
\hline Sampling sites & $(n)$ & Pearson product-moment correlations $(r)$ and $p$ values \\
\hline $\begin{array}{l}\text { All } \\
(\text { not Cel) }\end{array}$ & (13) & $\begin{array}{l}\text { Integrated CP: } N^{*}(0.72, p=0.005) \text {; Mixed layer average CP: } N^{*}(0.76, p=0.002) \\
\text { Relative E. huxleyi abundance: } \Omega_{\mathrm{C}}(-0.66, p=0.014) \text {; cell-CF: ML-D }(0.74, p=0.004)\end{array}$ \\
\hline $\begin{array}{l}\text { Stratified } \\
\text { (not Cel, sNS, Hel) }\end{array}$ & $(11)$ & $\begin{array}{l}\text { Integrated CP: } \operatorname{Ed}_{[\mathrm{ML}]}(0.91, p=0.0001) ; \text { Mixed layer average } \mathrm{CP}: \operatorname{Ed}_{[\mathrm{ML}]}(0.90, p=0.0001) \text {; } \\
\text { Coccolithophore abundance: ML-D }(-0.75, p=0.008), \mathrm{Ed}_{[\mathrm{ML}]}(0.72, p=0.013) ; \\
\text { Relative } E . \text { huxleyi abundance: ML-D }(-0.89, p=0.0002), \mathrm{ML}_{\mathrm{D}}: Z_{\text {eup }}(-0.86, p=0.001) ; \\
\text { cell-CF: ML-D }(0.75, p=0.008)\end{array}$ \\
\hline $\begin{array}{l}\text { E. huxleyi dominated } \\
\text { (not Cel, BBa, BBb, PEA) }\end{array}$ & $(10)$ & $\begin{array}{l}\text { Integrated CP: } N^{*}(0.77, p=0.009) \text {; Mixed layer average CP: } N^{*}(0.80, p=0.006) \\
\text { cell-CF: ML-D }(0.91, p=0.0003), \text { ML-D: } Z_{\text {eup }}(0.91, p=0.0003), \mathrm{Ed}_{[0+]}(0.83, p=0.003)\end{array}$ \\
\hline $\begin{array}{l}\text { E. huxleyi dominated } \\
\text { (not Cel, BBa, BBb, PEA, Hel) }\end{array}$ & (9) & $\begin{array}{l}\text { Integrated CP: } \operatorname{Ed}_{[\mathrm{ML}]}(0.93, p=0.0002) \text {; Mixed layer average } \mathrm{CP}: \mathrm{Ed}_{[\mathrm{ML}]}(0.90, p=0.0009) \text {; } \\
\text { Coccolithophore abundance: } \operatorname{Ed}_{[\mathrm{ML}]}(0.83, p=0.005) \text {; cell-CF: } \operatorname{ML}-\mathrm{D}(0.91, p=0.0007), \\
\text { ML-D: } Z_{\text {eup }}(0.88, p=0.002), \operatorname{Ed}_{[0+]}(0.79, p=0.012)\end{array}$ \\
\hline
\end{tabular}
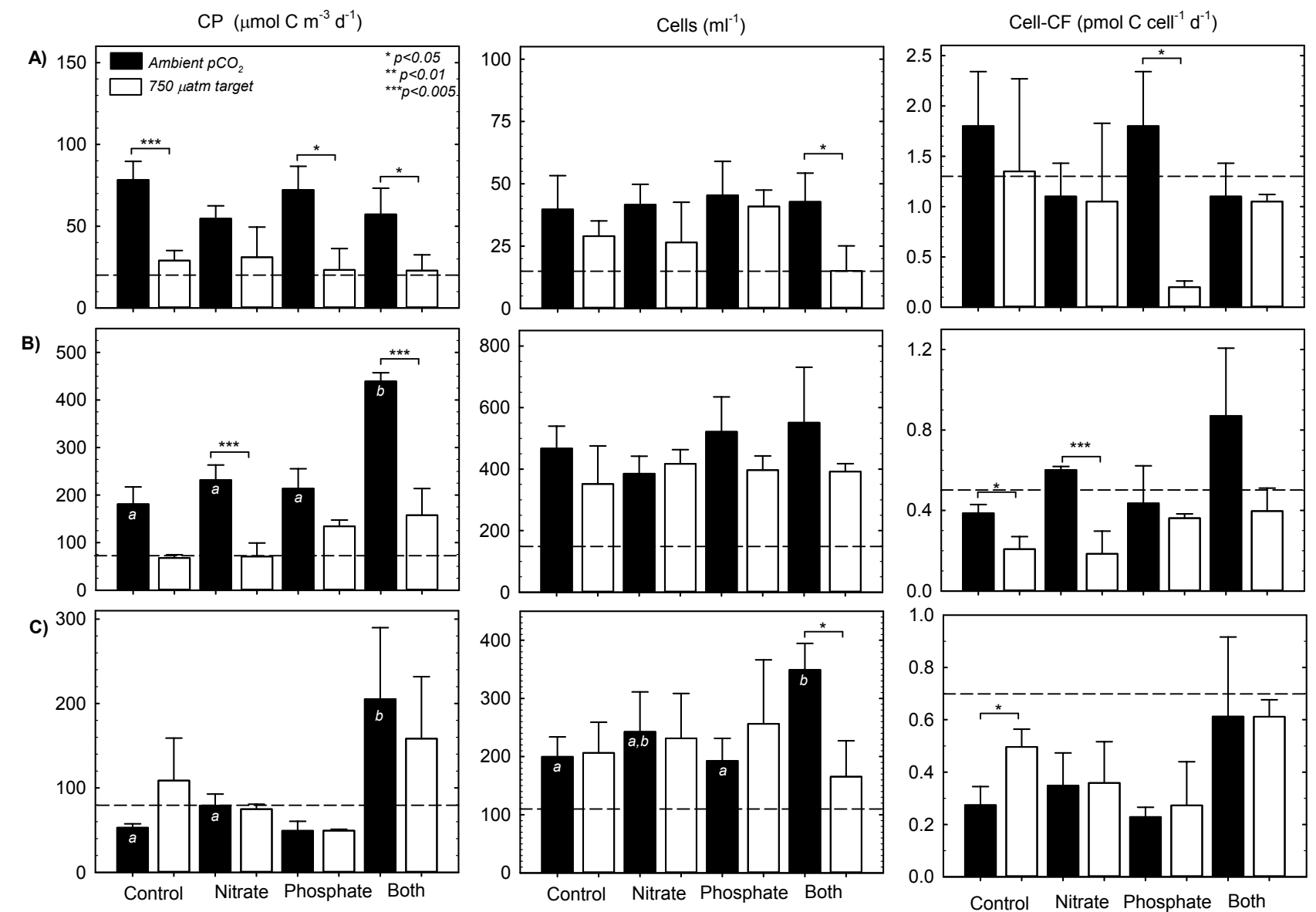

Figure 7. Results from nutrient and/or $p \mathrm{CO}_{2}$ amendment experiments for calcite production (CP), coccosphere abundance (cells) and cell-normalised calcification (cell-CF). Experiments are from (A) Bay of Biscay, (B) northern North Sea and (C) Norwegian Trench. Dashed lines indicated average initial rates and standing stocks. Asterisks indicate significant results from pairwise $t$ tests between ambient and target $750 \mu$ atm treatments: $* p<0.05, * * p<0.01, * * * p<0.005$. Letters indicate significant $(p<0.05)$ groupings from one-way ANOVA and pairwise $t$ tests between nutrient treatments and controls.

treatments, although the difference was lower in the $750 \mu$ atm target $p \mathrm{CO}_{2}$ treatments than in the ambient one (Table 5). In terms of $\mathrm{CP}$, there was no significant difference with respect to $p \mathrm{CO}_{2}$ level, but there was a significant (one-way ANOVA, $p<0.05)$ nutrient treatment effect, with the $+\mathrm{NP}$ treatment being much higher than the control or $+\mathrm{N}$ at ambient $p \mathrm{CO}_{2}$ 
Table 5. Average $( \pm \mathrm{sd})$ values for variables in the short-term $(48 \mathrm{~h})$ bioassay experiments. Experimental treatments are as follows: $+\mathrm{N}$ is $2 \mu \mathrm{mol} \mathrm{kg}{ }^{-1}$ nitrate and silicate; $+\mathrm{P}$ is $0.2 \mu \mathrm{mol} \mathrm{kg}{ }^{-1}$ phosphate and $2 \mu \mathrm{mol} \mathrm{kg}{ }^{-1}$ silicate; and $+\mathrm{NP}$ is $2 \mu \mathrm{mol} \mathrm{kg} \mathrm{kg}^{-1}$ nitrate and silicate and $0.2 \mu \mathrm{mol} \mathrm{kg}^{-1}$ phosphate. Bioassay experiment numbers (2B, 4B and $5 \mathrm{~B}$ ) refer to the entirety of the cruise bioassays (see Richier et al., 2014a).

\begin{tabular}{|c|c|c|c|c|c|c|c|c|}
\hline Bioassay & Treatment & $\begin{array}{l}p \mathrm{CO}_{2} \\
(\mu \mathrm{atm})\end{array}$ & $\mathrm{pH}_{\mathrm{T}}$ & $\Omega_{\mathrm{C}}$ & $\mathrm{NO}_{\mathrm{X}}$ & 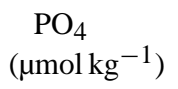 & $\mathrm{dSi}$ & $\begin{array}{l}\text { Total Chl } \\
\left(\mathrm{mg} \mathrm{m}^{-3}\right)\end{array}$ \\
\hline \multirow{9}{*}{$\begin{array}{l}\text { Bay of } \\
\text { Biscay } \\
(2 B)\end{array}$} & Initial & 340.3 & 8.1 & 4.4 & $0.9(0.1)$ & $0.1(0.0)$ & $1.2(0.0)$ & $0.6(0.1)$ \\
\hline & Ambient, control & $330.0(3.7)$ & $8.1(0.0)$ & $4.5(0.0)$ & $0.2(0.0)$ & $0.0(0.0)$ & $1.2(0.1)$ & $1.4(0.0)$ \\
\hline & Ambient, $+\mathrm{N}$ & $340.8(7.7)$ & $8.1(0.0)$ & $4.3(0.1)$ & $2.3(0.1)$ & $0.0(0.0)$ & $3.2(0.1)$ & $1.5(0.3)$ \\
\hline & Ambient, $+\mathrm{P}$ & $333.0(2.2)$ & $8.1(0.0)$ & $4.4(0.0)$ & $0.2(0.1)$ & $0.2(0.0)$ & $3.2(0.0)$ & $1.4(0.1)$ \\
\hline & Ambient, $+\mathrm{NP}$ & $341.7(5.5)$ & $8.1(0.0)$ & $4.3(0.1)$ & $2.3(0.1)$ & $0.3(0.0)$ & $3.2(0.0)$ & $1.3(0.1)$ \\
\hline & 750, control & $660.6(6.5)$ & $7.9(0.0)$ & $2.7(0.0)$ & $0.8(0.0)$ & $0.1(0.0)$ & $1.2(0.0)$ & $0.4(0.0)$ \\
\hline & $750,+\mathrm{N}$ & $686.0(12.4)$ & $7.8(0.0)$ & $2.6(0.0)$ & $2.8(0.1)$ & $0.1(0.0)$ & $3.2(0.1)$ & $0.5(0.1)$ \\
\hline & $750,+\mathrm{P}$ & $690.5(6.2)$ & $7.8(0.0)$ & $2.6(0.0)$ & $0.8(0.0)$ & $0.3(0.0)$ & $3.2(0.0)$ & $0.4(0.1)$ \\
\hline & $750,+\mathrm{NP}$ & $685.5(15.0)$ & $7.8(0.0)$ & $2.6(0.1)$ & $3.0(0.0)$ & $0.3(0.0)$ & $3.2(0.0)$ & $0.5(0.0)$ \\
\hline \multirow{9}{*}{$\begin{array}{l}\text { Northern } \\
\text { North Sea } \\
\text { (4B) }\end{array}$} & Initial & 327.3 & 8.1 & 4.0 & $0.3(0.0)$ & $0.0(0.0)$ & $0.3(0.0)$ & $0.5(0.0)$ \\
\hline & Ambient, control & $328.2(7.8)$ & $8.1(0.0)$ & $4.0(0.1)$ & $0.2(0.0)$ & $0.0(0.0)$ & $2.2(0.1)$ & $0.9(0.1)$ \\
\hline & Ambient, $+\mathrm{N}$ & $321.4(3.5)$ & $8.1(0.0)$ & $4.1(0.0)$ & $1.9(0.1)$ & $0.0(0.0)$ & $2.2(0.0)$ & $1.0(0.1)$ \\
\hline & Ambient, $+\mathrm{P}$ & $325.3(8.7)$ & $8.1(0.0)$ & $4.0(0.1)$ & $0.2(0.0)$ & $0.2(0.0)$ & $2.2(0.0)$ & $0.9(0.1)$ \\
\hline & Ambient, $+\mathrm{NP}$ & $322.6(8.8)$ & $8.1(0.0)$ & $4.0(0.1)$ & $1.3(0.1)$ & $0.1(0.0)$ & $2.3(0.0)$ & $1.9(0.2)$ \\
\hline & 750, control & $703.9(0.4)$ & $7.8(0.0)$ & $2.2(0.0)$ & $0.3(0.1)$ & $0.0(0.0)$ & $2.2(0.0)$ & $0.4(0.1)$ \\
\hline & $750,+\mathrm{N}$ & $698.6(9.7)$ & $7.8(0.0)$ & $2.2(0.0)$ & $2.3(0.1)$ & $0.0(0.0)$ & $2.3(0.0)$ & $0.6(0.1)$ \\
\hline & $750,+\mathrm{P}$ & $701.2(35.8)$ & $7.8(0.0)$ & $2.2(0.1)$ & $0.3(0.0)$ & $0.2(0.0)$ & $2.2(0.0)$ & $0.6(0.0)$ \\
\hline & $750,+\mathrm{NP}$ & $682.4(30.9)$ & $7.8(0.0)$ & $2.3(0.1)$ & $2.3(0.0)$ & $0.2(0.0)$ & $2.3(0.0)$ & $0.7(0.0)$ \\
\hline \multirow{9}{*}{$\begin{array}{l}\text { Norwegian } \\
\text { Trench } \\
\text { (5B) }\end{array}$} & Initial & 310.7 & 0.1 & 3.9 & $0.3(0.0)$ & $0.0(0.0)$ & $0.0(0.0)$ & $0.8(0.0)$ \\
\hline & Ambient, control & $324.0(8.0)$ & $8.1(0.0)$ & $3.7(0.1)$ & $0.3(0.0)$ & $0.0(0.0)$ & $1.8(0.0)$ & $0.6(0.0)$ \\
\hline & Ambient, $+\mathrm{N}$ & $312.3(8.8)$ & $8.1(0.0)$ & $3.8(0.1)$ & $1.7(0.0)$ & $0.0(0.0)$ & $1.7(0.0)$ & $1.0(0.0)$ \\
\hline & Ambient, $+\mathrm{P}$ & $340.7(8.2)$ & $8.1(0.0)$ & $3.6(0.1)$ & $0.3(0.0)$ & $0.1(0.0)$ & $1.8(0.0)$ & $0.6(0.1)$ \\
\hline & Ambient, $+\mathrm{NP}$ & $316.3(10.4)$ & $8.1(0.0)$ & $3.8(0.1)$ & $0.9(0.1)$ & $0.1(0.0)$ & $1.7(0.0)$ & $1.7(0.1)$ \\
\hline & 750, control & $671.0(34.5)$ & $7.8(0.0)$ & $2.1(0.1)$ & $0.3(0.0)$ & $0.0(0.0)$ & $1.8(0.0)$ & $0.4(0.1)$ \\
\hline & $750,+\mathrm{N}$ & $665.9(17.4)$ & $7.8(0.0)$ & $2.1(0.0)$ & $1.9(0.1)$ & $0.0(0.0)$ & $1.8(0.0)$ & $0.7(0.1)$ \\
\hline & $750,+\mathrm{P}$ & $674.8(20.3)$ & $7.8(0.0)$ & $2.1(0.1)$ & $0.3(0.0)$ & $0.1(0.0)$ & $1.9(0.0)$ & $0.4(0.0)$ \\
\hline & $750,+\mathrm{NP}$ & $692.9(19.4)$ & $7.8(0.0)$ & $2.1(0.1)$ & $1.5(0.2)$ & $0.1(0.0)$ & $1.7(0.1)$ & $1.1(0.1)$ \\
\hline
\end{tabular}

(Fig. 7c). Cell numbers showed a significantly $(p<0.05)$ higher value between $p \mathrm{CO}_{2}$ levels in the +NP treatment only, whereas cell-CF was significantly different $(p<0.05)$ between $p \mathrm{CO}_{2}$ levels in the control treatment. Cell numbers also responded to nutrient amendment, with cell numbers being significant higher (one-way ANOVA, $p<0.05$ ) in the $+\mathrm{NP}$ treatment at ambient $p \mathrm{CO}_{2}$ (Fig. 7c). Although there was a strong response to nutrients in the third bioassay, this was only found at ambient $p \mathrm{CO}_{2}$, not at elevated $p \mathrm{CO}_{2}$ and was completely absent in cell-CF at both $p \mathrm{CO}_{2}$ levels ( $p=0.16$ for ambient and $p=0.32$ for $750 \mu$ atm).

\section{Discussion}

\subsection{Coccolithophore production in NW European shelf waters}

During June 2011, coccolithophores were a consistent component of phytoplankton communities around the NW Euro- pean shelf, present at almost all sampling sites from openocean and shelf-break communities to those in shelf waters under both stratified and mixed physical regimes. Following the spring diatom-dominated bloom, the phytoplankton community during summer 2011 was dominated by small $(<10 \mu \mathrm{m})$ autotrophs (Fig. 4; Table 2), apart from at a few sampling sites in specific environments such as Heligoland (Lawson, 2013). Estimates of coccolithophore contributions to total chlorophyll biomass and primary production were generally $<3 \%$ and $<5 \%$ of nanoplankton $(<10 \mu \mathrm{m})$ primary production (Table 2). Exceptions to these low contributions were found during the first sampling of the coccolithophore bloom at the Western English Channel Observatory (E1) and in the diatom bloom (mainly Guinardia flacccida) at the Heligoland site (Lawson, 2013).

The high coccolithophore abundance $\left(>800\right.$ cells $\left.\mathrm{mL}^{-1}\right)$ and high rates of $\mathrm{CP}$ at Heligoland (Fig. 5), alongside the highest total $\mathrm{Chl}$ and PP of the cruise (Table 2), are somewhat of a surprise. Although this site had the highest integrated CP 
of the entire cruise, rather than the coccolithophore blooms at E1 and North Sea sites, coccolithophores (E. huxleyi) still only contributed $3 \%$ to total primary production and $\sim 20 \%$ towards the small proportion of nanoplankton primary production occurring at this site (Table 2). A rough estimate of $E$. huxleyi $\mathrm{Chl}$ contribution, based on average mixed layer cell numbers (Table 3$)$ and $\mathrm{Chl}\left(\sim 4.5 \mathrm{mg} \mathrm{m}^{-3}\right)$ and a cellular Chl content of $\sim 0.2 \mathrm{pg} \mathrm{Chl} \mathrm{cell}{ }^{-1}$ (Haxo, 1985), indicates that $E$. huxleyi also only contributed $\sim 4 \%$ of total autotrophic community Chl. Heligoland was also a fully mixed (bottom depth $42 \mathrm{~m}$ ) site, with low mixed layer irradiances $\left(<3\right.$ mol photons $\left.\mathrm{m}^{-2} \mathrm{~d}^{-1}\right)$, excess nitrate relative to phosphate, high dSi concentrations (Table 1) and large $(>50 \mu \mathrm{m})$ diatom cellular abundances $>60 \mathrm{cells} \mathrm{mL}^{-1}$ (Lawson, 2013), i.e. conditions not generally associated with intense coccolithophore blooms (see Iglesias-Rodriguez et al., 2002; Paasche, 2002; Tyrrell and Merico, 2004).

During June 2011, we also sampled several nanoflagellatedominated communities with integrated $\mathrm{Chl}>60 \mathrm{mg} \mathrm{m}^{-2}$ and primary production $>150 \mathrm{mmol} \mathrm{C} \mathrm{m}^{-2} \mathrm{~d}^{-1}$, including Mingulay Reef and the PEACE site (Table 2). These nanoflagellate "blooms" were associated with shelf-break and open-ocean conditions, with coccolithophores (an obvious component of the nanoflagellate community) only representing $\sim 1 \%$ of nanoflagellate primary production (Table 2). In fact, despite the dominance of the nanoplankton size-range in shelf waters around the NW European shelf during summer, coccolithophores were not an important constituent of these plankton communities.

Apart from Heligoland, we also sampled two other sites (E1, North Sea) with high $\left(>400\right.$ cells $\left.\mathrm{mL}^{-1}\right)$ coccolithophore cell numbers and $\mathrm{CP}$ rates (Fig. 5) as well as high detached coccolith concentrations $\left(>40-50 \times 10^{3} \mathrm{~mL}^{-1}\right.$ based on SEM counts; Poulton, unpublished). In the case of $\mathrm{E} 1$, integrated $\mathrm{CP}$ was $>3 \mathrm{mmol} \mathrm{C} \mathrm{m} \mathrm{d}^{-2} \mathrm{~d}^{-1}$, while in the North Sea integrated CP was $<2 \mathrm{mmol} \mathrm{C} \mathrm{m}^{-2} \mathrm{~d}^{-1}$ (Table 2). Other studies in shelf sea environments have observed a similar range of integrated $\mathrm{CP}$ values in bloom conditions: 1.2$11.5 \mathrm{mmol} \mathrm{C} \mathrm{m}^{-2} \mathrm{~d}^{-1}$, North Sea 1999 (Rees et al., 2002); $1.2-11.6 \mathrm{mmol} \mathrm{C} \mathrm{m}^{-2} \mathrm{~d}^{-1}$, Celtic Sea 2004 (Harlay et al., 2010); and 0.4-7.3 mmol C m ${ }^{-2} \mathrm{~d}^{-1}$, Patagonian Shelf 2008 (Poulton et al., 2013). Satellite images have shown that the central North Sea bloom sampled during 2011 was at its most intense around 2-3 weeks before sampling (see Fig. 1 in Krueger-Hadfield et al., 2014), and hence our in situ measurements were post-bloom. At the E1 and North Sea sites, coccolithophore contributions to total and nanoplankton primary production (Table 2$)$ were relatively low $(<10 \%$ and $<25 \%$, respectively) compared with similar estimates in coccolithophore blooms $(\sim 30-40 \%)$ (see Poulton et al., 2007, 2013).

Globally, coccolithophores are estimated to generally contribute $1-10 \%$ of total primary production in open-ocean environments ranging from the subtropics to the subpolar Iceland Basin (Poulton et al., 2007, 2010). Hence, the low contributions in shelf waters around the NW European shelf $(<3 \%)$ fit with the global picture of coccolithophores as minor contributors to total phytoplankton community biomass and primary production. Even within coccolithophore blooms, characterised by high concentrations of detached coccoliths and standing stocks of calcite, coccolithophores often represent $<40 \%$ of total primary production (Poulton et al., 2007, 2013). Clearly, a major role of coccolithophores in pelagic communities is due to the formation of calcite rather than primary production, and coccolithophores thus occupy the key role in global pelagic calcite production and export (Broecker and Clark, 2009).

Despite small contributions to pelagic primary production, the $\mathrm{CP}$ rates measured in shelf waters were of the same magnitude as those measured in similar studies in shelf waters and oceanic coccolithophore blooms (see Poulton et al., 2007, 2013). The cruiseaverage integrated $\mathrm{CP}\left(2.6 \mathrm{mmol} \mathrm{m}^{-2} \mathrm{~d}^{-1}\right)$ is equivalent to $0.26 \mathrm{~g} \mathrm{CaCO}_{3} \mathrm{~m}^{-2} \mathrm{~d}^{-1}$ (molecular weight of $\mathrm{CaCO}_{3}$ taken as 100), which is only slightly lower than the $0.36 \mathrm{~g} \mathrm{CaCO}_{3} \mathrm{~m}^{-2} \mathrm{~d}^{-1}$ average for measurements taken during late summer in the Iceland Basin (Poulton et al., 2010) but $\sim 100-1000$ times lower than estimates of calcification rates by benthic invertebrates such as echinoderms and molluscs in shelf waters (e.g. Lebrato et al., 2010). Hence, although coccolithophore contributions to pelagic calcite production over the shelf are significant, benthic calcite production is much higher and likely to be the dominant process in shallow $(<200 \mathrm{~m})$ waters (Lebrato et al., 2010).

\subsection{Coccolithophore calcification in relation to hydrography and nutrients}

Discrete measurements of CP generally decrease with irradiance through the water column (Fig. 5), showing no obvious sub-surface maxima, even when sub-surface chlorophyll maxima were evident in the $\mathrm{Chl}$ profiles (e.g. Celtic Sea, E1b, Shetland; Fig. 3). The same lack of vertical structure is also seen in cell-CF (Fig. 6) and confirms earlier field observations of the strong (vertical) light-dependency of calcification (Poulton et al., 2007, 2010). Estimates of cell-CF also had a similar range $\left(0.1-1.0 \mathrm{pmol} \mathrm{Cell}^{-1} \mathrm{~d}^{-1}\right.$; Table 3) to that found in other studies where E. huxleyi was dominant, for example the Iceland Basin (0.30.8 pmol C cell ${ }^{-1} \mathrm{~d}^{-1}$; Poulton et al., 2010) and Patagonian Shelf (0.1-0.6 pmol Ceell ${ }^{-1} \mathrm{~d}^{-1}$; Poulton et al., 2013). Values above 1.5 pmol Cell $^{-1} \mathrm{~d}^{-1}$ occurred at sites (Bay of Biscay, PEACE site) where other species (G. muellerae, Syracosphaera spp.) were present and which have potentially higher cellular inventories of calcite and hence higher cell-specific rates, a trend also seen in Arctic cell-CF measurements where species other than E. huxleyi were present (Charalampopoulou et al., 2011).

Absolute nutrient concentrations had little influence on bulk $\mathrm{CP}$ or cell-CF at the sampling sites in this study, whereas 
the nitrate-to-phosphate availability (expressed as $N^{*}$ ) was correlated $(p<0.01)$ with integrated and mixed layer average $\mathrm{CP}$ at all sites, as well as at those where E. huxleyi dominated (Table 4). However, when the Heligoland site is excluded from this analysis, no correlations are seen with $N^{*}$ (Table 4), and hence the correlations observed between $N^{*}$ and $\mathrm{CP}$ are driven by the unique nature of the Heligoland site (high $\mathrm{CP}$, high $N^{*}$ ) rather than anything else.

In contrast to macronutrients, various characteristics of the light environment (e.g. average mixed layer irradiance $\left.\left(\bar{E} \mathrm{~d}_{[\mathrm{ML}]}\right)\right)$ did show relationships to both the coccolithophore community CP and cell-CF (Table 4). Previous work has found linkages between $\bar{E} \mathrm{~d}_{[\mathrm{ML}]}$ and species composition (Charalampopoulou et al., 2011), and in our measurements from the north-west European Shelf, we also see significant correlations between integrated $\mathrm{CP}$, average mixed layer $\mathrm{CP}$ and coccolithophore cellular abundance at stratified sites and at those where E. huxleyi dominates (excluding Heligoland) (Table 4). Hence, coccolithophore community size (cellular abundance) and CP appear linked to the availability of light within the mixed layer.

Interestingly, cell-CF did not correlate with $\bar{E} \mathrm{~d}_{[\mathrm{ML}]}$ but rather with mixed layer depth (ML-D), incidental irradiance at the sea surface $\left(\mathrm{Ed}_{[0+]}\right)$ and the ratio of ML-D to euphotic zone depth $\left(Z_{\text {eup }}\right)$ (Table 4$)$. This is slightly surprising since cell-CF is an "instantaneous" measure of coccolithophore calcification, potentially linked to cellular physiology and growth rates (Poulton et al., 2010), and might be expected to respond to short-term changes in irradiance rather than water-column structure and stability (i.e. ML-D). However, cell-CF did correlate with incidental irradiance $\left(\operatorname{Ed}_{[0+]}\right)$, which varies in absolute terms with daily weather conditions rather than water-column structure (ML-D). Taken together, these correlations between coccolithophore community $\mathrm{CP}$ and cell-CF highlight how light availability exerts a strong influence on pelagic calcite production and coccolithophore calcification.

In contrast to the in situ observations, the nutrient addition bioassays (Fig. 7) revealed strong but variable responses from coccolithophores to the addition of nitrate $(+N)$, phosphate $(+\mathrm{P})$ or both $(+\mathrm{NP})$, with the bioassays showing stronger coccolithophore responses to nutrient addition in shelf environments (northern North Sea, Norwegian Trench) than in the open ocean (Bay of Biscay). Notably, the response to nutrient addition was limited to the ambient $p \mathrm{CO}_{2}$ treatments in all experiments (see Sect. 4.3). The response to nutrient addition may also be linked to species composition, with the two shelf bioassays showing strong responses to $+\mathrm{NP}$ being dominated by E. huxleyi, whereas the experiment exhibiting no response to nutrients had a mixed oceanic coccolithophore community of E. huxleyi and G. muellerae. In the northern North Sea (Fig. 7b), community CP increased significantly $(p<0.05)$ in response to $+\mathrm{NP}$ addition, with the response being mediated by an increase in cell-CF, although no significant difference to the control was found.
These changes in cell-CF in the northern North Sea bioassay are well within the range reported for E. huxleyi in both field (0.3-0.8 pmol C cell ${ }^{-1} \mathrm{~d}^{-1}$; Poulton et al., 2010) and culture conditions $\left(0.2-0.8 \mathrm{pmol} \mathrm{Cell}^{-1} \mathrm{~d}^{-1}\right.$; Balch et al., 1996b). Around the Norwegian Trench (Fig. 7c), community $\mathrm{CP}$ also increased significantly $(p<0.05)$ in response to $+\mathrm{NP}$ addition and this response was mediated by a significant $(p<0.05)$ increase in cell numbers. In the open ocean (Fig. 7a), the mixed coccolithophore community of E. huxleyi and $G$. muellerae showed no response to nutrient addition, suggesting that other factors, such as light availability and/or micro-zooplankton grazing were regulating the coccolithophore community in the Bay of Biscay at the time of sampling.

Variability in coccolithophore community CP can be caused by changes in either the abundance of coccolithophore cells or cell-CF (Poulton et al., 2010), and it appears that both factors change in response to $+\mathrm{NP}$ during summer in E. huxleyi-dominated shelf waters around the NW European Shelf (Fig. 7b and c). Estimating (net) growth rates based on the change in cell numbers between initial samples (dashed lines on Fig. 7) and samples $48 \mathrm{~h}$ later give rates ranging from 0.5 to $0.7 \mathrm{~d}^{-1}$ in the North Sea and 0.3 to $0.6 \mathrm{~d}^{-1}$ over the Norwegian Trench (data not shown). The sharp increase in CP over the Norwegian Trench is seen as an approximate doubling of net growth rates between the control $\left(0.3 \mathrm{~d}^{-1}\right)$ and $+\mathrm{NP}\left(0.6 \mathrm{~d}^{-1}\right)$ treatments. In this bioassay, cell-CF was lower than initial values for all treatments apart from the $+\mathrm{NP}$ one which was approximately equal $\left(0.6 \mathrm{pmol} \mathrm{C} \mathrm{cell}^{-1} \mathrm{~d}^{-1}\right)$ to the initial rate $\left(0.7\right.$ pmol C cell $\left.{ }^{-1} \mathrm{~d}^{-1}\right)$ (Fig. 7c). In contrast, in the North Sea the net growth rates are similar across all treatments $\left(0.6 \mathrm{~d}^{-1}\right.$ in control and $0.7 \mathrm{~d}^{-1}$ in $\left.+\mathrm{NP}\right)$, while the cell-CF in the $+\mathrm{NP}$ treatment $\left(0.8 \mathrm{pmol} \mathrm{C}\right.$ cell $\left.{ }^{-1} \mathrm{~d}^{-1}\right)$ is one of the few to be higher than the initial rate $\left(0.5\right.$ pmol C cell $\left.^{-1} \mathrm{~d}^{-1}\right)$.

Coccolithophores (E. huxleyi) in shelf waters in summer 2011 only responded when both nitrate and phosphate were added together rather than one or the other alone, and responded through either an increased growth rate and stable cell-CF (Norwegian Trench, Fig. 7c) or through stable growth rates and increased cell-CF (North Sea, Fig. 7b). Nitrate and phosphate availability appeared to be the important factor regulating growth rates and cell-CF of $E$. huxleyi in NW European shelf waters (North Sea, Norwegian Trench) whereas other factors, such as irradiance and/or mortality, appeared more important in the open ocean (Bay of Biscay). This contrasts with the in situ results which showed no relationships with nutrient concentrations, either absolute or relative to one another, across the sampling sites (Table 4).

\subsection{Coccolithophore calcification in relation to carbonate chemistry}

In situ measurements showed only one relationship to a parameter of the carbonate chemistry: a significant $(p<0.01)$ 
inverse correlation between $\Omega_{\mathrm{C}}$ and $E$. huxleyi dominance (Table 4). Across the sites sampled around the NW European shelf in June 2011, $\mathrm{pH}_{\mathrm{T}}$ varied by $\sim 0.09$ units (8.04 to 8.13 ) while calcite saturation state $\left(\Omega_{\mathrm{C}}\right)$ varied by $\sim 0.7$ units (3.60 to 4.36). Hence, this scale of variability in either $\mathrm{pH}_{\mathrm{T}}$ or $\Omega_{\mathrm{C}}$ did not appear to be enough to show a clear impact on the coccolithophore community in shelf waters in summer. In contrast, Charalampopoulou et al. (2011) found a change in species composition with variability in $\mathrm{pH}_{\mathrm{T}}$ of 0.4 units $(8.05$ to 8.45 ) and 0.9 units (3.5 to 4.4 ) in $\Omega_{\mathrm{C}}$ along a transect from the North Sea to the Arctic. Similarly, Smith et al. (2012) observed changes in dominant $E$. huxleyi morphotypes in the Bay of Biscay between winter and summer with changes in $\mathrm{pH}_{\mathrm{T}}$ of $\sim 0.06$ units (8.06 to 8.13) and $\sim 1.6$ units (3.6 to 5.2) in $\Omega_{\mathrm{C}}$. However, Poulton et al. $(2011,2013)$ found differences of $\sim 0.4$ units (7.9 to 8.3) of $\mathrm{pH}_{\mathrm{T}}$ and $\sim 2.3$ units (3.2 to 5.5) of $\Omega_{\mathrm{C}}$ along the Patagonian Shelf, with the E. huxleyi bloom at that time in waters at the low end of both the $\mathrm{pH}$ and $\Omega_{\mathrm{C}}$ gradient. Clearly, the response of coccolithophore $\mathrm{CP}$ and community composition to carbonate chemistry is more complex than a simple inverse linear response.

Importantly, around the NW European Shelf in June 2011 no co-variability of $\mathrm{pH}$ or $\Omega_{\mathrm{C}}$ was observed with the other growth-limiting factors (e.g. temperature). This contrasts with other studies where variability in coccolithophore dynamics across $\mathrm{pH}$ or $\Omega_{\mathrm{C}}$ gradients (e.g. Charalampopoulou et al., 2011; Smith et al., 2012; Poulton et al., 2011, 2013) are associated with co-varying gradients in growth-limiting factors such as temperature, nutrient concentrations and light availability. This contrast in coccolithophore response to $\mathrm{pH}$ or $\Omega_{\mathrm{C}}$, between gradients where carbonate chemistry covaries with other environmental parameters and gradients where there is no co-variability implies that any correlation between $\mathrm{pH}$ or $\Omega_{\mathrm{C}}$ and coccolithophore dynamics along environmental gradients should be viewed with caution and in the context of any naturally occurring co-correlation with nutrient and light availability.

With this context in mind, it is useful to consider the $p \mathrm{CO}_{2}$ and nutrient manipulation experiments carried out in June 2011. In this case, the $\mathrm{pH}_{\mathrm{T}}$ and $\Omega_{\mathrm{C}}$ conditions were changed drastically compared with the natural gradients present in June 2011 , with $\mathrm{pH}_{\mathrm{T}}$ reduced by $\sim 0.3$ units and $\Omega_{\mathrm{C}}$ reduced by $\sim 1.8$ units (Table 5 ). Such changes were enforced on the ambient populations within $<12 \mathrm{~h}$, which represents a much faster shift in carbonate chemistry than will be experienced through ocean acidification over the next century. Hence, the bioassays tested coccolithophore sensitivity to sharp changes in carbonate chemistry rather than acclimation to ocean acidification processes occurring over decades per se. In this context, even results generated through long-term experiments (Lohbeck et al., 2012; Jin et al., 2013) must be interpreted with caution, as the timescale is still an order of magnitude lower than the hundreds of generations or adaptation periods of microbes to ocean acidification in nature (Richier et al., 2014a).
Given these abrupt changes in carbonate chemistry $\left(\mathrm{pH}_{\mathrm{T}}\right.$, $\Omega_{\mathrm{C}}$ ), strong differences in CP, cell numbers and cell-CF between ambient and the higher $p \mathrm{CO}_{2}$ treatment $(750 \mu \mathrm{atm}$ $p \mathrm{CO}_{2}$ target) are not unsurprising (Fig. 7). An effect of increasing $p \mathrm{CO}_{2}$ was observed in all three bioassays, although it was more evident in the first two (Bay of Biscay, North Sea) than the third (Norwegian Trench). These effects of elevated $p \mathrm{CO}_{2}$ in the bioassays appear independent of species composition as they occur in either mixed coccolithophore communities of E. huxleyi and G. muellerae (Bay of Biscay) or monospecific E. huxleyi communities (North Sea, Norwegian Trench). As with the response to nutrient addition, the response to sharp changes in $\mathrm{pH}_{\mathrm{T}}$ and $\Omega_{\mathrm{C}}$ were seen in both cell numbers and cell-CF.

In the Norwegian Trench bioassay (Fig. 7a), significant $(p<0.05)$ reductions in CP between ambient and elevated $p \mathrm{CO}_{2}$ were linked to decreases in cell numbers (and growth rates: $0.1 \mathrm{~d}^{-1}$ in high $p \mathrm{CO}_{2}$ and $0.5 \mathrm{~d}^{-1}$ in ambient) in the $+\mathrm{NP}$ treatment and decreases in cell-CF in the $+\mathrm{P}$ treatment. In the North Sea bioassay (Fig. 7B), significant $(p<0.005)$ reductions in CP were linked to decreases in cell- $\mathrm{CF}$ in the control and $+\mathrm{N}$ treatment, and in the case of $+\mathrm{NP}$ a sharp increase in cell-CF under ambient conditions $\left(0.8 \mathrm{pmol} \mathrm{Ceell}^{-1} \mathrm{~d}^{-1}\right)$, while the cell-CF under elevated $p \mathrm{CO}_{2}\left(0.4 \mathrm{pmol} \mathrm{Cell}^{-1} \mathrm{~d}^{-1}\right)$ was more similar to the initial cell-CF $\left(0.5 \mathrm{pmolC}^{-1} \mathrm{cell}^{-1} \mathrm{~d}^{-1}\right)$. In the third bioassay over the Norwegian Trench (Fig. 7c), no clear differences in $\mathrm{CP}$ were evident and (net) growth rates were relatively slow $\left(0.2-0.4 \mathrm{~d}^{-1}\right)$ in all treatments apart from $+\mathrm{NP}\left(0.6 \mathrm{~d}^{-1}\right)$ under ambient conditions, and the coccolithophore community here seemed the least sensitive to extreme $p \mathrm{CO}_{2}$ changes over $48 \mathrm{~h}$.

Across the three experiments, $\mathrm{CP}$ was noticeably higher than initial values in only the ambient conditions, apart from in the third bioassay where only the $+\mathrm{NP}$ treatments were higher (Fig. 7). This trend is in contrast to that seen in cell numbers: cell numbers were higher in both ambient and elevated $p \mathrm{CO}_{2}$ treatments relative to the initial values, apart from in the case of $+\mathrm{NP}$ in the first bioassay (Fig. 7a). Hence, the coccolithophore communities almost always had positive (net) growth rates, despite the $p \mathrm{CO}_{2}$ manipulation. For cell$\mathrm{CF}$, the first bioassay (Bay of Biscay) had similar values at the end relative to the initial, while in the second bioassay, and especially in the third, cell-CF was lower than initial values (Fig. 7). Again, the coccolithophore response to experimental manipulation (in this case via $p \mathrm{CO}_{2}$ ) was mediated by changes in cell numbers (growth rates) and cell-CF, and the sensitivity of the different coccolithophore communities sampled to extreme $p \mathrm{CO}_{2}$ changes was highly variable. This pattern of response (i.e. changes in growth rate and/or cell$\mathrm{CF}$ ) is generally consistent with that seen in coccolithophore bloom communities in experimental mesocosms exposed to different $p \mathrm{CO}_{2}$ levels (Engel et al., 2005).

Of the three coccolithophore communities exposed to rapid changes in $\mathrm{pH}_{\mathrm{T}}$ and $\Omega_{\mathrm{C}}$ over short time periods (48 $\mathrm{h}$ ) 
in this study, the response in terms of $\mathrm{CP}$, cell- $\mathrm{CF}$ and coccolithophore cell numbers was muted in the slower-growing coccolithophore community (Norwegian Trench) indicating either reduced sensitivity or that the experiment was too short to detect changes. Similar results were obtained in terms of phytoplankton biomass and productivity at this location in longer-term (96h) bioassays (Richier et al., 2014a). The response in $\mathrm{CP}$ and cell-CF to nutrient addition was rapid and clearly detectable in both the fast- and slow-growing coccolithophore communities of the North Sea and Norwegian Trench, but only under ambient $p \mathrm{CO}_{2}$. The lack of response to nutrient addition by coccolithophores at elevated $p \mathrm{CO}_{2}$ implies that the coccolithophore communities were unable to respond to nutrient addition and failed to utilise nutrients to the same degree as under ambient $p \mathrm{CO}_{2}$. Similar conclusions were drawn from trends in total phytoplankton biomass and production in the long-term $p \mathrm{CO}_{2}$ bioassay experiments (Richier et al., 2014a) which ran in parallel to the experiments presented here. Richier et al. (2014a) suggest that the suppression of net growth of the small cells $(<10 \mu \mathrm{m})$ in the long-term $p \mathrm{CO}_{2}$ experiments is consistent with cell-sizespecific differences in levels of adaptation to naturally experienced fluctuations in carbonate chemistry species within the environment, as previously hypothesised by Flynn et al. (2012). However, neither the short-term experiments (presented here) or the long-term experiments (Richier et al., 2014a) were designed to specifically examine this hypothesis, and hence we cannot unequivocally relate the responses observed to specific physiological mechanisms.

Generally, the response of the coccolithophore communities sampled in shelf waters in June 2011 to changing carbonate chemistry was variable, with negative responses to decreasing $\mathrm{pH}$ in two of the short-term experiments and no response in a third. Little to no response was seen along the natural gradient in $\mathrm{pH}_{\mathrm{T}}$ and $\Omega_{\mathrm{C}}$ sampled during the cruise, which may either mean that the gradients were not strong enough to detect a response and/or that the coccolithophore communities sampled were perfectly adapted to local variations of in situ carbonate chemistry. Recent analysis of longterm observations of coccolithophores in the North Sea has shown an increase in coccolithophore occurrence over the last few decades, despite a trend of decreasing $\mathrm{pH}$ (Beare et al., 2013). Our study also highlights that these variable responses to carbonate chemistry in NW European shelf waters, which are undoubtedly complex, appear mediated by changes in growth rates and/or cellular calcification and interlinked with other growth-limiting factors (irradiance, nutrients).

\section{Conclusions}

During June 2011 coccolithophores formed only a small $(<5 \%)$ contribution to total primary production in waters around the NW European shelf, despite the dominance of phytoplankton community biomass and primary production by nanoflagellates $(<10 \mu \mathrm{m})$ (Table 2$)$. There was also an obvious shelf-oceanic divergence in coccolithophore species composition, with monospecific E. huxleyi communities on the shelf and a more mixed coccolithophore community, including G. muellerae, offshore. These differences were evident in patterns of cell-specific calcification (cell-CF) and the coccolithophore response to nutrient additions in the experimental bioassays (Fig. 7). Light availability, as indicated by mixed layer average irradiance $\left(\bar{E}_{[\mathrm{ML}]}\right)$ and incidental irradiance $\left(\operatorname{Ed}_{[0+]}\right)$, was correlated with community $\mathrm{CP}$ and cell-CF (Table 4) for both shelf and oceanic coccolithophore communities. In terms of the sharp changes in $\mathrm{pH}$ and $\Omega_{\mathrm{C}}$ experienced by the coccolithophore community in the bioassays, responses to elevated $p \mathrm{CO}_{2}$ occurred in both shelf and oceanic coccolithophore communities and decreases in CP were mediated by reductions in growth rates and cell-CF. While the response to nutrient addition appeared linked to species composition in shelf and oceanic coccolithophore communities, the response to elevated $p \mathrm{CO}_{2}$ was independent of species composition and linked to initial growth rates of the coccolithophore community. Such short-term experiments may not be indicative of future impacts from ocean acidification on coastal coccolithophore communities but do provide information on the relative sensitivity of natural coccolithophores to sharp changes in $p \mathrm{CO}_{2}$.

Acknowledgements. Financial support for A. J. Poulton came from NERC via a postdoctoral fellowship (NE/F015054/1) and from the UK Ocean Acidification research programme (NE/H017097/1). Support for co-authors also came from UKOA via NERC grants NE/H017097/1 to M. C. Stinchcombe, NE/H01718/1 to J. R. Young, NE/H017062/1 to D. J. Suggett, NE/H017348/1 to S. Richier, C. Dumousseaud and E. P. Achterberg, and NE/H017038/1 to D. C. E. Bakker and G. A. Lee We would also like to thank the officers and crew of the RRS Discovery, the technical staff from the National Marine Facilities and Toby Tyrrell as lead PI for the "Sea surface consortium". Further thanks go to Rob Thomas (BODC), Stephanie Henson (NOC) and Mariana Ribas-Ribas (University of Southampton) for help with access to MODIS satellite images and cruise data. MODIS Aqua satellite data was obtained from the NASA Ocean Colour distributed archive (http://oceancolor.gsfc.nasa.gov/). Finally, we would like to thank the editor J.-P. Gattuso and three anonymous reviewers for their helpful comments, which greatly improved the manuscript.

Edited by: J.-P. Gattuso 


\section{References}

Bakker, D. E. and Lee, G. A.: In situ observations of dissolved inorganic carbon, alkalinity and the partial pressure of carbon dioxide, in: Cruise report D366/367, 6th June-10th July 2011, edited by: Richier, S., 27-31, UK Ocean Acidification Research Program, 2012.

Bakker, D. C. E., Nielsdóttir, M. C., Morris, P. J., Venables, H. J., and Watson, A. J.: The island mass effect and biological carbon uptake for the subantarctic Crozet Archipelago, Deep-Sea Res. Pt. II, 54, 2174-2190, 2007.

Balch, W. M., Kilpatrick, K. A., Holligan, P., Harbour, D., and Fernandez, E.: The 1991 coccolithophore bloom in the central North Atlantic. 2. Relating optics to coccolith concentration, Limnol. Oceanogr., 41, 1684-1696, 1996a.

Balch, W. M., Fritz, J. J., and Fernández, E.: Decoupling of calcification and photosynthesis in the coccolithophore Emiliania huxleyi under steady-state light-limited growth, Mar. Ecol.-Prog. Ser., 142, 87-97, 1996b.

Balch, W. M., Drapeau, D. T., and Fritz, J. J.: Monsoonal forcing of calcification in the Arabian Sea, Deep-Sea Res. Pt. II, 47, 13011337, 2000.

Beare, D., McQuatters-Gollop, A., van der Hammen, T., Machiels, M., Teoh, S. J., and Hall-Spencer, J. M.: Long-term trends in calcifying plankton and $\mathrm{pH}$ in the North Sea, PLoS ONE, 8, e61175, doi:10.1371/journal.pone.0061175, 2013

Bibby, T. S. and Moore, C. M.: Silicate : nitrate ratios of upwelled waters control the phytoplankton community sustained by mesoscale eddies in sub-tropical North Atlantic and Pacific, Biogeosciences, 8, 657-666, doi:10.5194/bg-8-657-2011, 2011.

Broecker, W. and Clark, E.: Ratio of coccolith $\mathrm{CaCO}_{3}$ to foraminifera $\mathrm{CaCO}_{3}$ in late Holocene deep sea sediments, Paleoceanograhy, 24, PA3205, doi:10.1029/2009PA001731, 2009.

Charalampopoulou, A., Poulton, A. J., Tyrrell, T., and Lucas, M. I.: Irradiance and $\mathrm{pH}$ affect coccolithophore community composition on a transect between the North Sea and the Arctic Ocean, Mar. Ecol.-Prog. Ser., 431, 25-43, 2011.

Dickson, A. G. and Millero, F. J.: A comparison of the equilibrium constants for the dissociation of carbonic acid in seawater media, Deep-Sea Res., 34, 1733-1743, 1987.

Dickson, A. G., Sabine, C. L., and Christian, J. R.: Guide to best practices for ocean $\mathrm{CO}_{2}$ measurements, PICES Special Publication 3, IOCCP report number 8, 191 pp., 2007.

Engel, A., Zondervan, I., Aerts, K., Beaufort, L., Benthien, A., Chou, L., Delille, B., Gattuso, J.-P., Harlay, J., Heemann, C., Hoffmann, L., Jacquet, S., Nejstgaard, J., Pizay, M.-D., RochelleNewall, E., Schneider, U., Terbrueggen, A., and Riebesell, U.: Testing the direct effect of $\mathrm{CO}_{2}$ concentration on a bloom of the coccolithophorid Emiliania huxleyi in mesocosm experiments, Limnol. Oceanogr., 50, 493-507, 2005.

Flynn, K. J., Blackford, J. C., Baird, M. E., Raven, J. A., Cark, D. R., Beardall, J., Brownlee, C., Fabian, H., and Wheeler, G. L: Changes in $\mathrm{pH}$ at the exterior surface of plankton with ocean acidification, Nat. Clim. Change, 2, 510-513, 2012.

Gattuso, J.-P., Lee, K., Rost, B., Schulz, K., and Gao, K.: Approaches and tools to manipulate the carbonate chemistry, in: Guide to best practices for ocean acidification research and data reporting, edited by: Riebesell, U., Fabry, V. J., Hansson, L., and Gattuso, J.-P., Luxembourg, Publications Office of the European Union, 2010.
Grasshoff, K., Ehrhardt, M., and Kremling, K.: Methods of seawater analysis, Weinhem, Verlag Chemie, 1983.

Harlay, J., Borges, A. V., Van der Zee, C., Delille, B., Godoi, R. H. M., Schiettecatte, L.-S., Roevros, N., Aerts, K., Lapernat, P.E., Rebreanu, L., Groom, S., Daro, M.-H., Van Grieken, R., and Chou, L.: Biogeochemical study of a coccolithophore bloom in the northern Bay of Biscay (NE Atlantic Ocean) in June 2004, Progr. Oceanogr., 86, 317-336, 2010.

Harlay, J., Chou, L., De Bodt, C., Van Oostende, N., Piontek, J., Suykens, K., Engel, A., Sabbe, K., Groom, S., Delille, B., and Borges, A. V.: Biogeochemistry and carbon mass balance of a coccolithophore bloom in the northern Bay of Biscay (June 2006), Deep-Sea Res. Pt. I, 58, 111-127, 2011.

Haxo, F. T.: Photosynthetic action spectrum of the coccolithophorid Emiliania huxleyi (Haptophceae): 19'-Hexanoyloxyfucoxanthin as antenna pigment, J. Phycol., 21, 282-287, 1985.

Head, R. N., Crawford, D. W., Egge, J. K., Harris, R. P., Kristiansen, S., Lesley, D. J., Marañón, E., Pond, D., and Purdie, D. A.: The hydrography and biology of a bloom of the coccolithophorid Emiliania huxleyi in the northern North Sea, J. Sea Res., 39, 255 266, 1998.

Hickman, A. E., Moore, C. M., Sharples, J., Lucas, M. I., Tilstone, G. H., Krivtsov, V., and Holligan, P. M.: Primary production and nitrate uptake within the seasonal thermocline of a stratified shelf sea, Mar. Ecol.-Prog. Ser., 463, 39-57, 2012.

Holligan, P. M., Viollier, M., Harbour, D. S., Camus, P., and Champagne-Philippe, M.: Satellite and ship studies of coccolithophore production along a continental shelf edge, Nature, 304, 339-342, 1983.

Holligan, P. M., Fernandez, E., Aiken, J., Balch, W. M., Boyd, P., Burkill, P. H., Finch, M., Groom, S. B., Malin, G., Muller, K., Trees, C., Turner, S. M., and van der Wal, P.: A biogeochemical study of the coccolithophore, Emiliania huxleyi, in the North Atlantic, Global Biogeochem. Cy., 7, 879-900, 1993a.

Holligan, P. M., Groom, S. B., and Harbour, D. S.: What controls the distribution of the coccolithophore, Emiliania huxleyi, in the North Sea?, Fish. Oceanogr., 2, 175-183, 1993 b.

Iglesias-Rodriguez, M. D., Brown, C. W., Doney, S. C., Kleypas, J., Kolber, D., Kolber, Z., Hayes, P. K., and Falkowski, P. G.: Representing key phytoplankton functional groups in ocean carbon cycle models: Coccolithophorids. Global Biogeochem. Cy., 16, GB1100, doi:10.1029/2001GB001454, 2002.

Jin, P., Gao, K., and Beardall, J.: Evolutionary responses of a Coccolithophorid Gephyrocapsa oceanica to ocean acidification, Evolution, 67, 1869-1878, 2013.

Johnson, K. M., Sieburth, J. McN., Williams, P. J. LeB., and Brandstrom, L.: Coulomeric total carbon dioxide analysis for marine studies: automatization and calibration, Mar. Chem., 21, 117133, 1987.

Knauss, J.: Chapter 2: A Stratified Ocean, in: Introduction to Physical Oceanography, Pearson, 1996.

Krueger-Hadfield, S. A., Balestreri, C., Schroeder, J., Highfield, A., Helaouët, P., Allum, J., Moate, R., Lohbeck, K. T., Miller, P., Riebesell, U., Reusch, T. B. H., Rickaby, R. E. M., Young, J. R., Hallegraeff, G., Brownlee, C., and Schroeder, D. C.: Genotying an Emiliania huxleyi (Prymnesiophyceae) bloom event in the North Sea reveals evidence of asexual reproduction, Biogeosciences Discuss., 11, 4359-4408, doi:10.5194/bgd-11-43592014, 2014. 
Lawson, H.: Distribution of diatoms and microzooplankton in the surface waters of the UK Shelf seas and the controlling environmental variables, M.Sc. thesis, University of Southampton, Southampton, UK, 48 pp., 2013.

Lebrato, M., Iglesias-Rodriguez, D., Feely, R. A., Greeley, D., Jones, D. O. B., Suarez-Bosche, N., Lampitt, R. S., Cartes, J. E., Green, D. R. H., and Alker, B.: Global contribution of echinoderms to the marine carbon cycle: $\mathrm{CaCO}_{3}$ budget and benthic compartments, Ecol. Monogr., 80, 441-467, 2010.

Lessard, E. J., Merico, A., and Tyrrell, T.: Nitrate: phosphate ratios and Emiliania huxleyi blooms, Limnol. Oceanogr., 50, 10201024, 2005.

Lohbeck, K. T., Riebesell, U., and Reusch, T. B. H.: Adaptive evolution of a key phytoplankton species to ocean acidification, Nat. Geosci., 5, 346-351, doi:10.1038/ngeo1441, 2012.

Mehrbach, C., Cuberson, C. H., Hawley, J. E., and Pytkowicz, R. M.: Measurement of the apparent dissociation constants of carbonic acid in seawater at atmospheric pressure, Limnol. Oceanogr., 18, 897-907, 1973.

Moore, C. M., Mills, M. M., Achterberg, E. P., Geider, R. J., LaRoche, J., Lucas, M. I., McDonagh, E. L., Pan, X., Poulton, A. J., Rijkenberg, M. J. A., Suggett, D. J., Ussher, S. J., and Woodward, E. M. S.: Large-scale distribution of Atlantic nitrogen fixation controlled by iron availability, Nat. Geosci., 2, 867-871, 2009.

Paasche, E.: A review of the coccolithophorid Emiliania huxleyi (Prymnesiophyceae), with particular reference to growth, coccolith formation, and calcification-photosynthesis interactions, Phycologia, 40, 503-529, 2002.

Paasche, E. and Brutak, S.: Enhanced calcification in the coccolithophorid Emiliania huxleyi (Haptophyceae) under phosphorus limitation, Phycologia, 33, 324-330, 1994.

Painter, S. C., Poulton, A. J., Allen, J. T., Pidcock, R., and Balch, W. M.: The COPAS'08 expedition to the Patagonian Shelf: Physical and environmental conditions during the 2010 coccolithophore bloom, Cont. Shelf. Res., 30, 1907-1923, 2010.

Pierrot, D. E., Lewis, E., and Wallace, D. W. R: MS Excel program developed for $\mathrm{CO}_{2}$ system calculations, Oak Ridge National Laboratory, Carbon Dioxide Information Analysis Centre, 105, US Department of Energy, Oak Ridge, 2006.

Poulton, A.: Primary production and calcite production from D366, discrete CTD measurements, British Oceanographic Data Centre - Natural Environmental Research Council, UK, doi:10/s8q, 2014.

Poulton, A. J., Adey, T. R., Balch, W. M., and Holligan, P. M.: Relating coccolithophore calcification rates to phytoplankton community dynamics: Regional differences and implications for carbon export, Deep-Sea Res. Pt. II, 54, 538-557, 2007.

Poulton, A. J., Charalampopoulou, A., Young, J. R., Tarran, G. A., Lucas, M. I., and Quartly, G. D.: Coccolithophore dynamics in non-bloom conditions during late summer in the central Iceland Basin (July-August 2007), Limnol. Oceanogr., 55, 1601-1613, 2010.

Poulton, A. J., Young, J. R., Bates, N. R., and Balch, W. M.: Biometry of detached Emiliania huxleyi coccoliths along the Patagonian Shelf, Mar. Ecol.-Prog. Ser., 443, 1-17, 2011.

Poulton, A. J., Painter, S. C., Young, J. R., Bates, N. R., Bowler, B., Drapeau, D., Lyczsckowski, E., and Balch, W. M.: The 2008 Emiliania huxleyi bloom along the Patagonian Shelf: Ecology, biogeochemistry and cellular calcification, Global Biogeochem. Cy., 27, 1-11, 2013.

Raitsos, D. E., Lavender, S. J., Pradhan, Y., Tyrrell, T., Reid, P. C., and Edwards, M.: Coccolithophore bloom size variation in response to the regional environment of the subarctic North Atlantic, Limnol. Oceanogr., 51, 2122-2130, 2006.

Raven, J. A. and Crawfurd, K.: Environmental controls of coccolithophore calcification, Mar. Ecol.-Prog. Ser., 470, 137-166, 2012.

Rees, A. P., Woodward, E. M. S., Robinson, C., Cummings, D. G., Tarran, G. A., and Joint, I.: Size-fractionated nitrogen uptake and carbon fixation during a developing coccolithophore bloom in the North Sea during June 1999, Deep-Sea Res. Pt. II, 49, 2905 2927, 2002.

Ribas-Ribas, M., Rérolle, V. M. C., Bakker, D. C. E., Kitidis, V., Lee, G. A., Brown, I., Achterberg, E. P., and Tyrrell, T.: Intercomparison of carbonate chemistry measurements on a cruise in northwestern European shelf seas, Biogeosciences Discuss., 11, 2793-2822, doi:10.5194/bgd-11-2793-2014, 2014a.

Ribas-Ribas, M., Achterberg, E. P., Archer, S., Bakker, D., Clark, D., Hopkins, F. E., Moore, C. M., Lawson, H. E., Lee, G., Palmer, M., Poulton, A., Richier, S., Shi, T., Stinchcombe, M., Suggett, D., Tyrrell, T., and Young, J.: UK Ocean Acidification programme D366 cruise around the British Isles CTD bottle sample measurements, British Oceanographic Data Centre - Natural Environmental Research Council, UK, doi:10/thr, 2014b.

Richier, S., Achterberg, E. P., Dumousseaud, C., Poulton, A. J., Suggett, D. J., Tyrrell, T., Zubkov, M. V., and Moore, C. M.: Carbon cycling and phytoplankton responses within highlyreplicated shipboard carbonate chemistry manipulation experiments conducted around Northwest European Shelf Seas, Biogeosciences Discuss., 11, 3489-3534, doi:10.5194/bgd-11-34892014, 2014a.

Richier, S., Achterberg, E. P., Archer, S., Bretherton, L., Brown, I., Clark, D., Dumousseaud, C., Holland, R. J., Hopkins, F. E., MacGilchrist, G. A., Moore, C. M., Poulton, A., Rees, A., Shi, T., Stinchcombe, M., Suggett, D., Zubkov, M. V., Young, J., and Tyrrell, T.: Ocean acidification impacts on Sea Surface biology and biogeochemistry in Northwest European Shelf Seas: a highreplicated shipboard approach. British Oceanographic Data Centre - Natural Environmental Research Council, UK, doi:10/s8r, 2014b.

Simpson, J. H. and Sharples, J.: Introduction to the Physical and Biological Oceanography of Shelf Seas, Cambridge University Press, 448 pp., 2012.

Smith, H., Tyrrell, T., Charalampopoulou, C., Dumousseaud, C., Legge, O. J., Birchenough, S., Pettit, L. R., Garley, R., Hartman, S. E., Hartman, M. C., Sagoo, N., Daniels, C. J., Achterberg, E. P., and Hydes, D. J.: Predominance of heavily calcified coccolithophores at low $\mathrm{CaCO}_{3}$ saturation during winter in the Bay of Biscay, P. Natl. Acad. Sci., 109, 8845-8849, 2012.

The Royal Society: Ocean Acidification due to increasing atmospheric carbon dioxide, Policy Document 12/05, London, The Royal Society, 2005.

Tyrrell, T. and Merico, A.: Emiliania huxleyi: bloom observations and the conditions that induce them, 75-90, in: Coccolithophores from molecular processes to global impact, edited by: Thierstein, H. R. and Young, J. R., Springer-Verlag, Heidelberg, 2004. 
Van der Wal, P., Kempers, R. S., and Veldhuis, M. J. W.: Production and downward flux of organic matter and calcite in a North Sea bloom of the coccolithophore Emiliania huxleyi, Mar. Ecol.Prog. Ser., 126, 247-265, 1995.

Widdicombe, C. E., Eloire, D., Harbour, D., Harris, R. P., and Somerfield, P. J.: Long-term phytoplankton community dynamics in the Western English Channel, J. Plankton Res., 32, 643$655,2010$.
Young, J. R. and Ziveri, P.: Calculation of coccolith volume and its use in calibration of carbonate flux estimates, Deep-Sea Res. Pt. II, 47, 4679-1700, 2000.

Young, J. R., Poulton, A. J., and Tyrrell, T.: Morphology of Emiliania huxleyi coccoliths on the North West European shelf - is there an influence of carbonate chemistry?, Biogeosciences Discuss., 11, 4531-4561, doi:10.5194/bgd-11-4531-2014, 2014. 